\title{
The human newborn's umwelt: Unexplored pathways and perspectives
}

\author{
Vanessa André $^{1}$ - Séverine Henry ${ }^{1}$ - Alban Lemasson ${ }^{1}$ - Martine Hausberger ${ }^{2}$. \\ Virginie Durier $^{2}$
}

Published online: 1 May 2017

(C) Psychonomic Society, Inc. 2017

\begin{abstract}
Historically, newborns, and especially premature newborns, were thought to "feel nothing." However, over the past decades, a growing body of evidence has shown that newborns are aware of their environment, but the extent and the onset of some sensory capacities remain largely unknown. The goal of this review is to update our current knowledge concerning newborns' perceptual world and how ready they are to cope with an entirely different sensory environment following birth. We aim to establish not only how and when each sensory ability arises during the pre-/postbirth period but also discuss how senses are studied. We conclude that although many studies converge to show that newborns are clearly sentient beings, much is still unknown. Further, we identify a series of internal and external factors that could explain discrepancies between studies, and we propose perspectives for future studies. Finally, through examples from animal studies, we illustrate the importance of this detailed knowledge to pursue the enhancement of newborns' daily living conditions. Indeed, this is a prerequisite for assessing the effects of the physical environment and routine procedures on newborns' welfare.
\end{abstract}

Keywords Fetus $\cdot$ Newborn $\cdot$ Reaction $\cdot$ Sensory perception

Gottlieb's (1971) thorough comparative analysis of the literature on animal and human sensory development evidenced a

Vanessa André

vanessa.andre@univ-rennes1.fr

1 Université de Rennes 1, Ethologie Animale et Humaine, EthoS, UMR 6552, CNRS, Université Caen Normandie, Rennes, France

2 CNRS, Ethologie Animale et Humaine, EthoS, UMR 6552, Université de Rennes 1, Université de Caen Normandie, Rennes, France seemingly invariant sequence of the onset of different sensory functions. All the sensory systems of the bird and mammal species studied develop before birth in a similar order. The sequential patterns are similar whatever the degree of development at birth. The tactile system is the first functional system and is active very soon after conception, followed by the vestibular, then chemical, auditory, and, finally, visual systems. This sequence has been described for altricial as well as for precocial species, although some of altricial species' systems (auditory and visual) develop only after birth (Alberts \& Ronca, 1993; Gottlieb, 1968, 1971). One consequence is that fetuses of different species not only develop in common environmental conditions but also share the same sequence of development of their perceptual experiences (Alberts \& Ronca, 1993). The gradual onset of sensory capacities - and thereby inputs - implies that the pattern of sensory stimulations is expected to progress during development increasing from a limited sensory world during the early stages of development to a wider and richer framework of perception later (pre- or postnatal stages). Authors argue that the early limitations are adaptive as they limit the quantities of inputs and thus interferences within and between senses (Turkewitz \& Kenny, 1982). Therefore, instead of considering the developing individual at different stages as an immature system not yet adapted, it should be considered as adapted for each developmental stage. In other words, fetuses and the subsequent young infants are not individuals with limited skills that are "handicaps to be overcome" but individuals with the capacities required at each particular stage of their development for normal (typical) maturation of the system (Alberts \& Cramer, 1988; Turkewitz \& Kenny, 1982). Individuals develop within the framework of an ontogenetic niche (i.e., mammals' maternal womb) that changes with time, therefore, development — in particular, behavioral development - is a series of adaptations to a series of ontogenetic niches (Alberts, 2008; Alberts \& Harshaw, 2014). This approach underscores the relationship between an individual's developing 
sensory abilities and its developmental environment, which induces constraints and therefore limits or enhances sensory inputs. From this point of view, ongoing sensory experiences shape subsequent sensory and, to a larger extent, behavioral development. As we discuss below, disrupting the dynamics of stimulations has neural and behavioral consequences (Lickliter, 2005).

In the context of human development, good knowledge of the perceptual sensitivities/abilities at birth are particularly important to promote adapted medical, nursing, and environmental care during the perinatal period. This is especially significant for high-risk infants, such as preterm infants, who may lack stimulations from their intrauterine developmental niche (i.e., vestibular or gustatory stimulations) and at the same time receive an excess of other stimulations from the new extrauterine environment (visual stimulations) (Lickliter, 2000). Although some sensory stimulations perceived after birth could have been perceived previously during the final fetal stages (e.g., maternal voice and odor; DeCasper \& Fifer, 1980; Schaal, Hummel, \& Soussignan, 2004), most sensory stimulations perceived after delivery are novel and intense (Bartocci et al., 2001; Darcy, Hancock, \& Ware, 2008; Lasky \& Williams, 2009; Livera et al., 2008; Prazad et al., 2008). At birth, newborns must be able to breathe through their nose, to feed by suckling, and to tolerate light. Background noise heterogeneity and temperature variations are also novel experiences in addition to many routine procedures performed after birth, such as administrating eye drops, taking blood samples, and other manipulations (diaper change, baths) that are sources of novel sensory stimulations which must be taken carefully into consideration in relation to their impact on newborns' welfare (Gibbins et al., 2008; Long, Philip, \& Lucey, 1980; Mörelius, Hellström-Westas, Carlén, Norman, \& Nelson, 2006; Owens \& Todt, 1984; Tristão, Garcia, de Jesus, \& Tomaz, 2013). In the past, invasive manipulations were performed without apprehension as newborns were considered to be insensitive to pain (Anand \& Hickey, 1987). Although this is no longer the case, the onset and the extent of their sensory capacities are still unclear.

Most reviews on newborns' sensory perception are now more than 10 years old (e.g., Kenner \& Lubbe, 2007; Lecanuet \& Schaal, 2002) or deal with only one or two sensory modalities (e.g., Browne, 2008; Hall, 2000; Schaal et al., 2004). Since these reviews, many reports have enhanced our knowledge. Therefore, it is timely to review our current knowledge concerning premature and full-term newborns' umwelt. The concept of umwelt was formulated by Jakob von Uexküll in 1934 to describe individuals' subjective universe determined by their sensory perceptions and cognitive abilities. Over the past decades, reports evidence that newborns perceive a wide range of stimulations from their environment. Our first goal of this review is to present an overview of our current knowledge of newborns' perception of sounds, flavors, odors, tactile and visual stimuli, and their development during the pre-/postbirth period. Because the perinatal period is a crucial moment, as it is the transition from the fetal to the postnatal stages, we focus here on the first few days after birth and the fetal stage when it can explain newborns' abilities. Our second goal is to examine discrepancies among results and interpretations. Therefore, we analyze in detail not only what studies tell us about newborns' senses but also how these senses are assessed. Thus, we identify a series of internal and external factors that could explain these discrepancies. In the last part, we propose perspectives for future research, based on research in animal models, and discuss the current predominant models of development.

One challenge is to pinpoint the precise onset of sensory perception for different modalities. Many studies test a sensory modality only when it is possible, which means that we know when it is functional but not when it started to function. In this review, we distinguish results of tests made at different stages of development until sensitivity arose from those obtained at a stage when no tests have been made earlier (we then specify: "at least at ...").

\section{Current knowledge of newborns' umwelt}

\section{Tactile perception}

Fetal stage Skin sensory receptors are present at least at 7 weeks post conception (PC) and are connected to the spinal cord at 8 weeks PC. However, connections between the spinal cord and the brain are established later and are not functional before 20 to 24 weeks PC (Anand \& Hickey, 1987; Glover \& Fisk, 1999; Hamon, 1996; Laquerrière, 2010).

An early study tested the reactions of aborted fetuses of different ages in response to tactile stimulations with the hair of an esthesiometer (Hooker, 1942). As the entire anatomical pathway was not completely achieved by the time of the experiment, the reactions were considered a spinal cord reflex (withdrawal). From this single study, it seems that at least at 7 weeks PC, stimulations of the face induce movements by the fetus and that during the following weeks of development, sensitivity extends along an anteroposterior axis to the entire body and is complete by 14 weeks PC (Hooker, 1952; Humphrey, 1978). During twin pregnancies, evoked movements (i.e., a movement of one fetus following a contact with the other fetus within seconds) have been recorded from the age of 12 weeks PC and their occurrence increases with age, illustrating maturation of tactile perception (Arabin, Geinbruch, \& von Eyck, 1993; Piontelli et al., 1997; Zimmer, Goldstein, \& Alglay, 1988). A few hand-head contacts can be observed at least at 10 weeks PC and their occurrence increases rapidly (de Vries, Visser, \& Prechtl, 1985). In parallel, thumb sucking is rarely observed before 15 weeks PC 
but becomes more frequent afterwards (Hepper, Shahidullah, \& White, 1991). A pressure on the maternal abdomen can also be perceived by the fetus (from 32 to 40 weeks PC) who reacts with co-occurring heart rate changes (Bradfield, 1961; Issel, 1983; Walker, Grimwade, \& Wood, 1973).

Reactions to tactile nociceptive stimulations can be revealed by fetuses' beta-endorphin and cortisol rates at least at 20 weeks PC as they increase after intrauterine needling (in the fetal innervated umbilical vein). This timing is concomitant with the first connections between the brain and the peripheral structures (Giannakoulopoulos, Glover, Sepulveda, Kourtis, \& Fisk, 1994).

After birth Numerous studies evidence that newborns react to painful procedures. At delivery, the rates of blood betaendorphin of full-term newborns extracted with forceps seem to be higher than after spontaneous vaginal delivery, suggesting pain perception in response to strong tactile stimulation (Puolakka, Kauppila, Leppäluoto, \& Vuolteenaho, 1982). After birth, newborns (premature and full term) react to a heel lance procedure with typical facial expressions (i.e., raising or lowering brow, narrowing or tightly closing eyes, wrinkling nose, and raising upper lip; Gibbins et al., 2008; Grunau \& Craig, 1987) and/or crying (Gaspardo, Miyase, Chimello, Martinez, \& Martins Linhares, 2008; Owens \& Todt, 1984). Invasive or noninvasive procedures can induce these behavioral expressions and cortical activation (Fabrizi et al., 2011; R. Slater et al., 2006; C. P. White \& Cooke, 1989), hormonal modifications, such as beta-endorphin and cortisol levels (Giannakoulopoulos et al., 1994; Mörelius et al., 2006; Puolakka et al., 1982), and oxygen consumption (Long, Lucey, \& Philip, 1980). For instance, from at least 25 weeks PC, nociceptive tactile stimulations induce an increase of oxygenation level (i.e., total hemoglobin concentration) in the contralateral somatosensory cortex, whereas no activation is observed in response to a soft touch (R. Slater et al., 2006).

Recent studies on haptic touch evidenced that before their fifth day of life, full-term newborns can discriminate object textures (Molina \& Jouen, 2003), weights (Hernandez-Reif, Field, Diego, \& Largie, 2001), or shapes (Streri, Lhote, \& Dutilleul, 2000). Premature newborns, at least at 28 weeks PC, can also discriminate different objects by their shape (Marcus, Lejeune, Berne-Audéoud, Gentaz, \& Debillon, 2012).

\section{Olfactory perception}

Fetal stage Olfaction involves three systems: the principal olfactory system that processes most odors (e.g., vanilla, chocolate), the trigeminal system that processes so-called tactile odors (e.g., mint, spice), and the vomeronasal system that processes pheromones (e.g., stress pheromone; Lecanuet \& Schaal, 1996). The development of electronic microscopy has facilitated investigation of the fetal olfactory sensory system. The principal olfactory system is mainly an epithelium composed of numerous hair cells that appear at 7 weeks PC and is proposed to be mature at 11 weeks PC (Piatkina, 1982). The trigeminal system appears at 4 weeks PC with the emergence of the trigeminal nerve. Finally, the vomeronasal fibers can be differentiated from those of the principal olfactory system as early as 7 weeks PC. The olfactory bulb appears at 6 weeks PC, and the first synapses between nasal fibers and cortex are functional at 7-8 weeks PC (Bossy, 1980; Piatkina, 1982). Although most elements of the olfactory system are present at 8 weeks PC, some only emerge later, such as the nasal receptors at 28 weeks PC (Chuah \& Zheng, 1987).

Due to amniotic fluids surrounding the fetus, responses related to olfactory abilities are difficult to dissociate from those due to gustative abilities at the fetal stage. Consequently, the earliest evidence of reactions to odors comes from studies of premature newborns tested with airborne odorants.

After birth Several authors report that newborns react to strong and subtle olfactory stimulations. At least at 28 weeks PC, premature newborns react to odors (e.g., vanilla, butyric acid, colostrum, milk) and discriminate between odors (vanilla vs. anise, for example; Goubet et al., 2002). Threeday-old full-term newborns respond behaviorally and physiologically to very subtle odors produced by areolar glands, whatever their feeding habits (Doucet, Soussignan, Sagot, \& Schaal, 2009). Newborns' olfactory perception appears to be highly responsive. The earliest evidence of reactions to more "tactile" olfactory stimulations (pungent odors like spicy or mint odors) can be observed from 29 weeks PC age. Indeed, after a mint odor stimulation, full-term and 32-week old PC premature newborns increase their global activity, but younger (28-week old PC) premature newborns rarely react (Sarnat, 1978). Behavioral (global activity, body agitation and facial grimaces) and cortical reactions indicate that full-term and premature newborns are able to detect odors like peppermint, disinfectants, or detergents (Bartocci et al., 2001; Bartocci et al., 2000; Gauthaman, Jayachandran, \& Prabhakar, 1984). Reactions to tactile olfactory stimulations that involve the trigeminal system are faster than reactions to other olfactory stimulations; for example, premature newborns react quicker to eucalyptol than to nonanoic acid (Pihet, Mellier, Bullinger, \& Schaal, 1997). A hedonic responsiveness of at least 31 weeks PC newborns to odors has been evidenced: smelling vanilla induces respiratory acceleration and more appetitive reactions (e.g., licking, sucking), whereas smelling butyric acid induces a decrease of respiration rates and facial expressions typical of disgust (e.g., wrinkling nose, raising upper lip, turning head away; Schaal et al., 2004).

According to numerous authors, full-term as well as premature newborns are able to memorize and recognize odors 
they are exposed to after birth. After a brief familiarization to an odor (10 presentations lasting 10 seconds each), premature newborns are able to discriminate between this odor and a novel odor (vanilla vs. anise) at least at 28-34 weeks PC (Goubet et al., 2002). Also, after a familiarization phase to a vanilla odor released in their incubator for 17 hours, premature newborns (around 32 weeks PC) express fewer pain reactions during a painful procedure performed concurrently with a vanilla odor release than did nonexposed newborns (Goubet, Rattaz, Pierrat, Bullinger, \& Lequien, 2003). This rapid postnatal learning is particularly efficient when olfactory perception is associated with suckling (Marlier, Schaal, \& Soussignan, 1998a, b). For example, an odor applied on their mother's breast or nipple during their first days of life becomes attractive for the exposed full-term newborns, even after very short and limited exposures (Delaunay-El Allam, Marlier, \& Schaal, 2006; Schleidt \& Genzel, 1990). Furthermore, 2-day-old breastfed full-term newborns do not show any preference for either their mother's colostrum or amniotic fluid (the chemosensory properties of both fluids are very similar). However 4-day-old newborns (after colostrum has been replaced by milk) orient their head more toward the milk odor than toward the amniotic fluid odor (Marlier et al., 1998b). On the contrary, bottle-fed newborns never prefer formula milk to their amniotic fluid, but the contrary (Marlier et al., 1998a). Breast-suckling seems to trigger odor learning and development of preferences.

Transnatal transmission Reactions to odors depend not only on perceptual abilities but also on previous exposure and possibly learning. Indeed, fetuses are exposed to odors during pregnancy. The amniotic fluid contains components that derive mainly from their mother's diet (Liley, 1972). Consequently, nutrients with strong odors, ingested during pregnancy (like cumin or curry, for instance) "imprint" the amniotic fluid with odors (e.g., Mennella, Johnson, \& Beauchamp, 1995; Schaal, Marlier, \& Soussignan, 1995). Fetal breathing movements induce a continuous movement of the amniotic fluid in contact with their nasal chemoreceptors (Badalian, Chao, Fox, \& Timor-Tritsch, 1993; Schaal et al., 2004). Thus, fetuses can perceive and memorize different odors. For example, when presented with an anise odor, full-term newborns of mothers who consumed anise during pregnancy orient their head more toward this odor than do nonexposed newborns who turn their head away (Schaal, Marlier, \& Soussignan, 2000). Anise was provided by the experimenters but was consumed on a voluntary basis. Therefore, inheritance of maternal taste preference cannot be ruled out, independently of the exposure to the substance in utero. However, many studies highlight newborns' olfactory learning competencies (Delaunay-El Allam et al., 2006; Goubet et al., 2002; Schleidt \& Genzel, 1990). Full-term newborns turn their head toward the odor of their own amniotic fluid more than toward that of unfamiliar amniotic fluids (Schaal et al., 1995; Schaal, Marlier, \& Soussignan, 1998). This preference for their own amniotic fluid after birth underscores the existence of transnatal memory of odors perceived in utero and recognized after birth.

\section{Gustatory perception}

Fetal stage Taste buds appear at 7 weeks PC and are fully developed at 14-15 weeks PC (Hersch \& Ganchrow, 1980; Witt \& Reutter, 1997), while gustative receptors, mainly localized within the taste buds, appear at 11-12 weeks PC and seem to be mature between 13 and 15 weeks PC (Bradley \& Stern, 1967). At this stage, the receptors could become functional as they are already connected to the taste buds through nervous fibers (Witt \& Reutter, 1998).

A pioneering study established that fetuses are able to swallow as early as 12 weeks PC (Pritchard, 1965), so their taste perception has been assessed by changing the composition of the amniotic fluid and recording subsequent modifications of swallowing rates. Swallowing rates of 34-week-old PC fetuses increases after an injection of saccharin and decreases after an injection of lipiodol into the amniotic fluid (Liley, 1972). Therefore, at least at 34 weeks PC, fetuses seem able to express gustatory preferences or at least to adapt their behavior in relation to what they perceive in the amniotic fluid.

After birth Few reports concern premature newborns' perception of gustatory components. Nevertheless, several convergent studies establish that as early as 2 hours after birth, full-term newborns' facial expressions change in reaction to intraoral gustatory stimulations. Water induces no particular facial expression, whereas sweet solutions can induce smiling or sticking their tongue out, and bitter or sour solutions induce arm movements, avoidance movements (turn head away) and grimaces including four typical facial expressions (raising or lowering brow, narrowing or tightly closing eyes, wrinkling nose, and raising upper lip; Ganchrow, Steiner, \& Daher, 1983; Steiner, 1979). These four typical facial expressions correspond to typical universal rejection responses also expressed by fetuses (Humphrey, 1970) and even adults (Craig, 1992). Distaste can be expressed in different ways. After tasting a bitter solution, newborns open their mouths, whereas they close them after tasting a sour solution (Ganchrow et al., 1983; Rosenstein \& Oster, 1988; Steiner, 1979; Steiner, Glaser, Hawilo, \& Berridge, 2001). Moreover, full-term and premature newborns ingest less and/or perform less teat suctions after tasting a sour, salty, or water solution than after tasting a sweet solution (Crook, 1978; Desor, Maller, \& Andrews, 1975; Tatzer, Schubert, Timischl, \& Simbruner, 1985). In conclusion, newborns' responsiveness clearly appears hedonic. Indeed, they prefer sweet solutions, 
show distaste for bitter and sour solutions, and are relatively indifferent to water and salt.

\section{Auditory perception}

Fetal stage Ears are composed of an inner, a middle and an external part. The inner and middle ears are involved in the transduction of sounds (Pujol \& Lavigne-Rebillard, 1992; Pujol, Puel, Gervais D'aldin, \& Eybalin, 1993). Anatomical studies show that the first hair cells appear in the inner ear at 11 weeks PC and are mature at 14 weeks PC (Pujol et al., 1993). The innervation of these cells starts at 20 weeks PC and is completed between 24 and 28 weeks PC (Pujol \& Lavigne-Rebillard, 1985; Pujol, Lavigne-Rebillard, \& Uziel, 1991). Using a method called "acoustic auto emission," Morlet et al. (1995) recorded low-intensity sounds produced by the hair cells of 30 weeks PC fetuses following a sound stimulation showing that hair cells can react to sounds at least at that age. The cochlea develops in the middle ear between 15 and 20 weeks PC (Pujol \& Lavigne-Rebillard, 1992).

The earliest clear evidence of auditory perception by fetuses is at least 19 weeks PC. Changes in body movements can be observed following continuous broadcast of a pure tone of $500 \mathrm{~Hz}$ with increasing intensity (from $65 \mathrm{~dB}$ to $120 \mathrm{~dB}$ ) through the maternal abdominal wall (Hepper \& Shahidullah, 1994). Fetuses also react to different external vibro-acoustical, musical or speech stimulations by changing their suction and heart rates (Kisilevsky et al., 2009; Kisilevsky, Pang, \& Hains, 2000; Leader, Baillie, Martin, \& Vermeulen, 1982; Petrikovsky, Schifrin, \& Diana, 1993; Visser, Mulder, Wit, Mulder, \& Prechtl, 1989).

After birth At birth, newborns are confronted directly with environmental auditory stimulations that are no longer softened by the maternal abdominal wall and the amniotic liquid (Gerhardt \& Abrams, 1996; Querleu, Renard, Versyp, ParisDelrue, \& Crèpin, 1988). Full-term and premature newborns respond to a range of auditory stimulations (e.g., clicks, bells ringing, vibro-acoustical stimulations) with various facial expressions and body movements coupled with cortical activation and changes in heart and respiration rates (Allen \& Capute, 1986; Rotteveel, de Graaf, Colon, Stegeman, \& Visco, 1987; Starr, Amlie, Martin, \& Sanders, 1977). Very premature newborns' (26-31 weeks PC) cerebral oxygen saturation and heart rates increase and their respiratory rates decrease in response to subtle variations $(5 \mathrm{~dB})$ of sound intensity (Kuhn et al., 2012). In another pragmatic way, activation of premature newborns' brain has been recorded at 3035 weeks PC (mean age $=34$ weeks PC), and this seems to indicate discrimination abilities between two vowels $(I$ and $Y$; Cheour-Luhtanen et al., 1996). Similarly, using suction rate and amplitude, full-term newborns differentiate between words of two and three syllables and between different one- syllable words (Bertoncini, Bijeljac-Babic, Blumstein, \& Mehler, 1987; Bijeljac-Babic, Bertoncini, \& Mehler, 1993).

Transnatal transmission Several studies evidence that repetitive exposure to particular sounds since the fetal stage induces learning. Indeed, fetuses perceive sounds produced by their own activity (Benzaquen, Gagnon, Hunse, \& Foreman, 1990; Querleu, Renard, Boutteville, \& Crepin, 1989), their mother's body (e.g., mother's respiration, heart rate), and their mother's environment, although the latter are filtered by the abdominal wall (Gerhardt \& Abrams, 1996; Querleu et al., 1988). A mother's voice transmits to her fetus better than other voices as it spreads both through air and through her body tissues and is heard more often than any other voice (e.g., Richards, Frentzen, Gerhardt, Mccann, \& Abrams, 1992). In utero, fetuses (at least at 33 weeks PC) react differently to their mother's voice than to another woman's voice (Kisilevsky et al., 2009). Then, 3 days after delivery, newborns discriminate between their mother's voice and an unfamiliar woman's voice, even when they have been separated from their mother for most of these 3 days (DeCasper \& Fifer, 1980). Fetuses and newborns are not only sensitive to their mother's voice but also to other types of acoustic flow, whether they are linguistic or not. Thus, fetuses (at least at 33 weeks PC) are able to discriminate between their native language and other languages (Kisilevsky et al., 2009). Full-term newborns of mothers exposed to a particular speech passage during the last 6 weeks of pregnancy suckle at higher rates during the reading of this passage than when an unfamiliar text is read (DeCasper \& Spence, 1986). Moreover, full-term newborns exposed to 4 hours of music during the 72 hours before delivery are more active when hearing this sound 3 to 5 days after birth than newborns who have never heard this sound before (James, Spencer, \& Stepsis, 2002). Finally, newborns who are regularly exposed to aircraft noise during their prenatal life react less to a similar sound after birth than do nonexposed babies (Ando \& Hattori, 1970). Thus, perception of environmental sounds during the fetal stage induces some early prenatal learning of vocal and nonvocal sounds and transnatal memory of these sounds.

\section{Visual perception}

Fetal stage The central zone of the retina (mainly composed of cones involved in chromatic vision) is not as fully developed at birth as the peripheral zones (mainly composed of rods involved in achromatic vision; Abramov et al., 1982). These peripheral zones (parafovea and midperipheral retina), where the photoreceptors develop from 26 weeks PC, are functional at birth (Hendrickson \& Drucker, 1992). The nervous connections develop slowly from 26 to 29 weeks PC and continue to develop up to 15 months after birth (Burkhalter, Bernardo, \& Charles, 1993). 
Reports show that fetuses react physiologically (increased heart rate) and behaviorally (body movements) to an extra uterine light (amnioscopy, light stimulation Kiuchi, Nagata, Ikeno, \& Terakawa, 2000; Peleg \& Goldman, 1980; Smyth, 1965). For instance, according to Fulford et al. (2003), fetuses of at least 36 weeks PC react to a constant-intensity light source diffused through the maternal abdomen by increased activity in their frontal cortex.

After birth Authors evidenced decades ago that newborns are able to perceive many nonsocial basic stimuli at birth. For example, premature newborns respond to a flash of light by cortical activation (evoked potential) from 23 to 24 weeks PC on (Chin, Taylor, Menzies, \& Whyte, 1985; Taylor, Menzies, MacMillan, \& Whyte, 1987), and blinking at least at 25 weeks PC (Allen \& Capute, 1986). According to Haynes, White, and Held (1965), newborns would be able to accommodate their vision to perceive images $19 \mathrm{~cm}$ away (images at shorter or longer distances would be blurred). When presented visual stimulations at 20 to $40 \mathrm{~cm}$, newborns appear particularly sensitive to black and white patterns, to contrasting variations, to vertical more than to horizontal bars and to patterned more than plain stimuli (A. M. Brown et al., 2015; Fantz, 1963; Miranda, 1970). From at least 34 weeks PC, newborns can perform ocular motility, object fixation, and detection and tracking of a moving target (Ball \& Tronick, 1971; Bidet-Ildei, Kitromilides, Orliaguet, Pavlova, \& Gentaz, 2014; Dunkeld \& Bower, 1980; Ricci, Cesarini, et al., 2008; Ricci, Romeo, et al., 2008; Ricci et al., 2010; Romeo et al., 2012), and recognition of an object independently of its state (moving or stationary; A. Slater, Morison, Town, \& Rose, 1985). Newborns are able to perceive directional movements (forward vs. backward optical flow movements) as they adapt their walking movements, the so called "newborn stepping," accordingly (Barbu-Roth et al., 2009; Barbu-Roth et al., 2014).

Newborns' visual abilities related to social stimuli have been widely investigated. Full-term newborns look longer at a normal face-like pattern than at a disordered/scrambled face pattern (Farroni et al., 2005) and longer at a human biological motion (translational displacement) than at any other kind of motion (Bidet-Ildei et al., 2014; Simion, Regolin, \& Bulf, 2008). They can differentiate familiar from unfamiliar faces (Di Giorgio, Leo, Pascalis, \& Simion, 2012), smiling from non-smiling faces (A. Slater et al., 1998) and are sensitive to gaze orientation (Farroni, Csibra, Simion, \& Johnson, 2002; Guellaï, Coulon, \& Streri, 2011; Guellaï \& Streri, 2011). Moreover, they are able to detect and to imitate adult facial expressions (Meltzoff \& Keith, 1977).

Finally, a wide range of studies conclude reliably that newborns possess important cognitive visual abilities. Full-term newborns are able to perceive subtle changes in size, grating density, shape (Streri \& Gentaz, 2004), quantity (two vs. three or four vs. six black dots; Antell \& Keating, 1983) and color, discriminating orange from red but not blue from gray (Adams, Courage, \& Mercer, 1991; Adams, Maurer, \& Cashin, 1990; Adams, Maurer, \& Davis, 1986).

Transnatal transmission Reports evidence prenatal light perception so the system must be functional at least partially before birth (Kiuchi et al., 2000; Peleg \& Goldman, 1980; Smyth, 1965). Del Giudice (2011) tried to model the possibility of light transmission to the uterine cavity on the basis of mother's abdominal thickness and clothes. According to this study, external light could cross these layers and the light intensity in the uterine cavity could be sufficient to enable fetal vision in particular contexts. This author hypothesizes that visual perception during fetal development could impact the development of visuomotor connections and postnatal outcomes. To our knowledge, no data sustain this hypothesis or any kind of transnatal transmission linked to prenatal visual information, but the possibility of prenatal visual experience suggests fascinating future research on visual transnatal transmission.

\section{Cross modality and laterality}

Cross modality Numerous recent studies evidence the capacities of human newborns to associate information from different sensory modalities, like touch and vision or vision and audition, to recognize a person or an object (for a review, see Lickliter \& Bahrick, 2007). Two hours after birth, newborns look longer at their mother's face than at an unfamiliar face, only if their mother has talked to them previously, so that they could associate her face with the voice heard and learned in utero (Coulon, Guellaï, \& Streri, 2011). In the same way, after a habituation period with a video of a speaking woman, newborns look more at this familiar face during a choice test, only if the sound of her voice is added to the image during the habituation period (Coulon et al., 2011; Guellaï et al., 2011). During their first days of life, they are also able to detect the congruence or incongruence between lip movements and a vowel sound. This demonstrates audiovisual connections (Coulon, Hemimou, \& Streri, 2013). Newborns can also transfer tactile/visual information. Less than 72 hours after birth, they are able to recognize objects visually (prism or cylinder) that they have held previously in their hand (Streri \& Gentaz, 2004). Newborns habituated either visually or tactilely to an object (either a smooth or a rough cylinder) explored the unfamiliar object longer than the one to which they had been familiarized when both objects were presented in the other modality of perception (tactile or visual; Sann \& Streri, 2007). Here again, they are able to transfer information perceived through one perceptual modality to another.

Laterality Lateralization has been deduced from observations indicating that fetuses and full-term newborns present a 
preferential head orientation (i.e., they turn their heads more often to the right than to the left; Rönnqvist \& Hopkins, 1998; Ververs, de Vries, van Geijn, \& Hopkins, 1994). According to Hammer and Turkewitz (1974), full-term newborns respond with increased heart rates and more head movements when stimulated with a supple brush on their right cheek than on their left cheek.

Moreover, a few studies suggest auditory laterality: Newborns would turn more often toward low intensity sounds (66 db) produced near their right ear and high intensity sounds $(87 \mathrm{db})$ near the left ear (Turkewitz, Birch, Moreau, Levy, \& Cornwell, 1966), and they seem to react more (suction rate) to a voice broadcast near their right ear and to music near their left ear (Bertoncini et al., 1989). Concurrently, newborns' electrical brain activity when listening to speech sounds is greater in the left than in the right hemisphere (Hahn, 1987).

In conclusion, from very early on, fetuses and newborns live in a rich sensory world. At birth, newborns are able to perceive subtle information through different sensory modalities (tactile, visual, olfactory, gustatory, and auditory) and to associate different types of information providing a multimodal knowledge of their environment. However, many questions concerning newborns' umwelt remain unsolved.

\section{Why does the newborns' umwelt remain largely unknown?}

The first part of this review clearly revealed the lack of information concerning many aspects of newborns' sensory world. In particular, the onset and the extent of their sensory abilities are still not clearly and fully characterized. Different factors can lead to discrepancies between results, some related to intrinsic factors (sex, age of the subjects), and others to extrinsic factors (environment, care practices) that may or may not have been taken into account, and of course methodologies used can differ greatly among studies investigating the same modality.

\section{Intrinsic factors}

Age Newborns' gestational age and age after birth, in hours or even days at the time of the tests, vary largely among studies (Adams et al., 1994; days after birth: Adams et al., 1990; Bartocci et al., 2001; Coulon et al., 2011; hours after birth: Farroni et al., 2002; Fulford et al., 2004; Goubet et al., 2002; Guellaï \& Streri, 2011; gestational age: Hykin et al., 1999; Sininger, Abdala, \& Cone-Wesson, 1997). Some studies do not even mention the precise age of their subjects, although age can be a major factor inducing discrepancy, given the maturation processes involved.

However, premature newborns differ from full-term babies in different ways. For instance, they have smaller skulls and weaker muscles, higher heart rates, and less pronounced variations between the different phases of sleep (Clairambault, Curzi-Dascalova, Kauffmann, Médigue, \& Leffler, 1992; Curzi-Dascalova, Peirano, \& Morel-Kahn, 1988; Eiselt et al., 1993; Forslund \& Bjerre, 1983; Joseph, Lesevre, \& Dreyfus-Brisac, 1976). Gestational age clearly impacts interindividual variations as only $46 \%$ of the premature newborns (32-34 weeks PC) react by changes in heart rate after an auditory stimulation, whereas $83 \%$ of the full-term newborns do (Kisilevsky \& Hains, 2011). Moreover, Fabrizi et al. demonstrated that the neural circuitry enabling to discriminate touch from nociception appears in late premature/early term newborns, that is, around 35-37 weeks PC. Reactions to tactile stimulations are therefore closely related to the subject's age. Few studies focus on differences between premature and full-term newborns' behavioral and physiological reactions. Nevertheless, authors evidence differences in the behavioral expression of stress. Premature newborns' cries are higher pitched and they horizontal-mouth-stretch more frequently than full-term newborns who show more taut tongues in response to nociceptive stimulations (Johnston, Stevens, Craig, \& Grunau, 1993). Thus, both perception and reactions can differ between premature and full-term subjects at the same postnatal age.

Three complementary studies underline the fact that age does not impact sensory modalities equally, and both prenatal and postnatal experiences play a major role in sensory maturation. The fact that the performances of premature newborns concerning some visual abilities (e.g., ocular motility, object tracking, fixation) are the same at birth (34-37 weeks PC) and at the expected term age suggests that they develop these abilities prenatally. However, postnatal experience appears crucial to acquire other visual abilities (e.g., attention at distance, ocular alignment and convergence). Indeed, premature newborns are more efficient at the expected term age than at birth and more efficient than full-term newborns of a similar conceptional age (Jandó et al., 2012; Romeo et al., 2012; Weinacht, Kind, Mönting, \& Gottlob, 1999).

Conclusion Future studies on sensory perception should consider gestational age systematically as well as precise age after birth. Moreover, both prenatal (infants of different gestational age tested at birth) and postnatal (infants of a same gestational age at birth tested at different ages postdelivery) maturations must be investigated separately as both phases differently impact newborns' development.

Sex Although it should be easy to take newborns' sex into account, this information is often missing or neglected even in recent studies. However, several authors agree that female and male newborns develop differently in some ways from very early on. According to Thordstein, Löfgren, Flisberg, Lindecrantz, and Kjellmer (2006), cortical functions mature 
earlier in females than in males (distributions of cortical activities differ between sexes during sleep and wakefulness), and male baseline heart rates are significantly lower than those of females' (Nagy, Orvos, Bárdos, \& Molnár, 2000). Consequently, sex may be a key player in perception or reaction to a given stimulus.

Few studies consider the impact of newborns' sex on their reactions to sensory stimulations. However, differences between males and females have been highlighted in response to sensory stimulations. For example, according to Friedman, Bruno, and Vietze (1974) after visual habituation to one stimulus, a female's attention (looking longer) is more sustained than that of a male when a new stimulus with subtle changes is introduced (gestational age at birth not specified in this study). Female full-term newborns appear more reactive to sounds, especially high-frequency sounds, than male newborns (Cassidy \& Ditty, 2001). Seventy-five percent of the female fetuses (25-26 weeks PC) move after vibro-acoustic stimulation through their mothers' abdominal wall, but only $33 \%$ of the male fetuses do (Leader et al., 1982).

Conclusion Very few studies compare female and male newborns' sensory abilities. However, the fact that differences have been evidenced between male and female adults' sensory perceptions highlights the need for a full range of new studies of newborns.

Arousal All day long, newborns oscillate between phases of sleepiness and wakefulness. Several states have been described for full-term (Prechtl, 1974) and premature newborns (Holditch-Davis, Scher, Schwartz, \& Hudson-Barr, 2004). Nevertheless, the assessment of a precise state remains difficult, and so is keeping a newborn in the targeted state for an experiment. Nevertheless, as biological cycles clearly impact newborns' heart and respiration rates as well as cortical activity (Clairambault et al., 1992; Curzi-Dascalova, Lebrun, \& Korn, 1983; Parmelee, Wenner, Akiyama, Schultz, \& Stern, 1967; Peirano, Curzi-Dascalova, \& Korn, 1986), their state of wakefulness could influence their perception of, and reactions to, stimulations. Unfortunately, only a few studies focus on the impact of newborns' arousal state on their sensory perception. The behavioral and physiological reactions of full-term newborns to sensory stimulations differ according to their arousal state. For example, changes in body temperature in response to an odor (e.g., milk, amniotic fluid, vanilla) are more pronounced when newborns are awake (eyes open and no or a few movements) or during irregular sleep (eyes closed, irregular respiration, a few small movements) than during regular sleep (eyes closed, regular respiration, and no movements; Soussignan, Schaal, Marlier, \& Jiang, 1997). Auditory sensory laterality seems to be influenced by wakefulness. According to Turkewitz et al. (1966), newborns react more to sounds broadcast on their right side when in a quiet sleep, but more to those broadcast on their left side when fully awake.

Conclusion Although a growing number of studies try to control arousal state, most studies do not mention the newborns' wakefulness level at the time of the experiment. It appears crucial, at least, to focus on a precise state to determine sensory perception or, better, to test this perception in different states.

\section{Extrinsic factors}

Delivery modalities Delivery is a moment when newborns experience major respiratory, physical, and sensory disruptions. Hence, stress level may vary according to delivery modalities (e.g., vaginal delivery with or without local anesthesia, breech presentation, instrumental delivery, cesarean section). However, most studies of newborns do not take this factor into account or even mention the type of birth. Others restrict their analyses to newborns born by vaginal delivery with or without local anesthesia (when stated). Finally, some mention their subjects' delivery modalities but do not evaluate their potential impact.

Nevertheless, several studies indicate an impact of delivery modality on newborns' physiology: concentrations of betaendorphins in full-term newborns' umbilical cords were higher after a vacuum extractor delivery than after a normal delivery (Puolakka et al., 1982), and umbilical cortisol concentrations (positively correlated with infant alertness) were higher when labor had been longer (Bell, White-Traut, Wang, \& Schwertz, 2012). Epidural analgesia seems to impact the alertness of newborns, impairing their neurobehavioral performances at least on the day following birth (Emory, Schlackman, \& Fiano, 1996). Thus, delivery modalities can impact newborns' reactions and probably perception.

Conclusion Despite the few data available, it appears important to take all the characteristics of the delivery process, from uterine posture to delivery modality and administration of anesthesia into account. As newborns' sensibility thresholds can vary according to type of birth.

Environmental characteristics and "routine" care procedures Human newborns are confronted with many external stimulations in the hospital environment (Bartocci et al., 2001; Darcy et al., 2008; Lasky \& Williams, 2009; Livera et al., 2008; Prazad et al., 2008). Nevertheless, reports on sensory perception rarely describe newborns' sensory environment in detail beyond the particular stimulations studied, although it can vary immensely between hospitals. Many studies underline a short-term impact of external sensory stimulations on physiological and behavioral measures of newborns (Bertelle, Mabin, Adrien, \& Sizun, 2005; Goubet et al., 2003; Jaldo- 
Alba, Muñóz-Hoyos, Molina-Carballo, Molina-Font, \& Acuña-Castroviejo, 1993; Philbin, 2000; Rivkees, Mayes, Jacobs, \& Gross, 2004; Weinert, Sitka, Minors, MennaBarreto, \& Waterhouse, 1997). For instance, premature newborns' sleep durations and weight gains are influenced by environmental conditions such as levels of noise and light (Bertelle et al., 2005; Mann, Haddow, Stokes, Goodley, \& Rutter, 1986). Intersensory interactions have been evidenced early after birth indicating that full-term newborns change their visual preference after an auditory stimulation with bursts of white noise (Lewkowicz \& Turkewitz, 1981). Therefore, unexpected and uncontrolled stimulations from the environment may impact the response to the targeted stimulation.

Neonatal care procedures differ according to the mothers' personal choice and the hospitals' practice guidelines. Feeding modality (breastfeeding vs. bottle feeding), practices of skinto-skin, practices of tight or loose swaddling, and/or repetition of painful procedures can influence sensory development and/ or reactions to stimulations. For instance, neonatal procedural pain exposures modify the threshold or intensity of reactions to subsequent stimulations (for review, see Grunau, Holsti, \& Peters, 2006).

Skin-to-skin impacts full-term and premature newborns' physiological stability, neurodevelopment, thermal and sleeping balance, food intake, and possibly survival (Bystrova et al., 2003; Feldman \& Eidelman, 2003; Ferber \& Makhoul, 2004; Lawn, Mwansa-Kambafwile, Horta, Barros, \& Cousens, 2010; Mikiel-Kostyra, Mazur, \& Boltruszko, 2002; Scher et al., 2009), especially when it occurs within the first 5 minutes post birth (Takahashi, Tamakoshi, Matsushima, \& Kawabe, 2011). Thus, premature newborns held skin to skin show fewer signs of pain and stress in response to a care procedure (reduced beta-endorphin and cortisol concentrations, shorter crying bursts, fewer grimaces and decreased heart rates) than newborns who were not held skin to skin (Gitau et al., 2002; Gray, Watt, \& Blass, 2000; Mooncey, Giannakoulopoulos, Glover, Acolet, \& Modi, 1997). More generally, developmental care procedures (low light and sound levels, postural and motor support) seem to decrease pain expressions and oxygen desaturation events during routine interventions (Sizun, Ansquer, Browne, Tordjman, \& Morin, 2002). Nevertheless, most perceptual studies neither describe nor obviously take into account these practices when analyzing reactions to sensory stimulations.

Conclusion Studies on perception should put greater weight on environmental conditions and nursing procedures experienced by newborns. These practices can influence levels of stress/comfort inducing various arousal states and consequently behavioral reactions. Overlooking these criteria may well impact interpretation of reactions to a stimulation by modifying at least sensory thresholds if not the whole perceptual range.

Socioemotional context Most studies do not describe or take into account the emotional states of mothers or of other people present (during pregnancy but also at the time of the test). However, recent studies are starting to draw attention to the influence of mothers' prenatal stress, which could induce a higher level of cortisol in response to a painful stress in newborns (Davis, Glynn, Waffarn, \& Sandman, 2011) and consequently influence the newborn's alertness (Bell et al., 2012).

A few authors agree on the fact that human fetuses perceive their mother's emotions. Fetuses increase their movements and decrease their respiration rates when their mother listens to music, and particularly when their mother likes that sound (Zimmer et al., 1982). An instantaneous cognitive stress perceived by the mother (through a cognitive task) enhances her fetus's heart rate variability whereas a more constant maternal stress (evidenced by a high level of cortisol) induces higher motor activity (DiPietro, Costigan, \& Gurewitsch, 2003; DiPietro, Kivlighan, Costigan, \& Laudenslager, 2009). Likewise, full-term newborns seem to be sensitive to the emotional context of social stimuli from their first days of life: Indeed, they are more attentive to a smiling than to a nonsmiling face (A. Slater et al., 1998) or to a happy than to an unhappy voice (Mastropieri \& Turkewitz, 1999).

Conclusion As newborns are sensitive to particular emotions, we speculate that the emotional state of the persons present during a test could influence newborns' reactions.

\section{Experimental measures and procedures}

Assessment methods and precision of data evaluations as well as stimulation procedures vary greatly among studies.

Data Measurement methods extend from physiological reactions (heart and/or respiratory rates, $\mathrm{O} 2$ saturation: Gaspardo et al., 2008; Gibbins et al., 2008; Johnston, Stevens, Yang, \& Horton, 1995; Owens \& Todt, 1984), hormonal changes (beta endorphin and cortisol concentrations: Giannakoulopoulos et al., 1994; Gitau et al., 2002), electrophysiological responses (skin conductance: Harrison et al., 2006; Tristão et al., 2013), cortical activity (electroencephalogram: Draganova et al., 2005; Fabrizi et al., 2011; Starr et al., 1977), to behavioral responses (Bertoncini et al., 1989; Guellaï \& Streri, 2011; Schaal et al., 1998). As already stated, expected responses should be adapted to the subject's characteristics. For example, cortical responses could change with age: after a visual stimulation, premature 24-week old PC newborns present a single positive peak of activity, whereas 36-week PC old newborns present a second negative peak (Taylor et al., 1987). 
Differences between authors' choices of criteria are less easy to understand. Thus, when measuring heart rate, some authors consider that "variations" of five beats/min during 5 seconds can be interpreted as a response to a stimulation, while for others, "variations" must exceed 15 beats/min during 15 seconds to reach the same conclusion, even for sameage subjects (Aladjem, Feria, Rest, \& Stojanovic, 1977; Issel, 1983; Kawakami et al., 2002; Walker et al., 1973).

Although behavioral observations have a great potential for the evaluation of newborns' sensory abilities, the behavioral analyses presented in many reports are based on the experimenter's subjective interpretation of the newborns' reactions, without any real quantification of their behavior (e.g., Adams et al., 1994). The most commonly used measures are scales that score zero or one (sometimes 0 to 3 ) a list of behavioral items like crying, body movements, facial expressions or general state (Debillon, Gras-Leguen, Boscher, \& Fleury, 1998; Grunau \& Craig, 1987; Ratynski, Cioni, Franck, Blanchard, \& Sizun, 2002; Stevens, Johnston, \& Horton, 1994). These scales are mainly qualitative and do not take into account quantitative variations of newborns' reactions. Moreover, they focus mainly on pain assessment (Gibbins et al., 2008; Grunau, Johnston, \& Craig, 1990). Here, again, measures have to take subjects' characteristics into consideration. For instance, in response to painful procedures, females present more facial expressions (Guinsburg et al., 1999) whereas males cry sooner (Grunau \& Craig, 1987). Therefore, according to the parameter chosen (face/sound), the conclusions can differ suggesting either that female or male babies are the more sensitive. As physiological measures, behavioral evaluations must be adapted to the age of the subject. For instance, premature newborns express less body and facial movements than do full-term newborns (Craig, Whitfield, Grunau, Linton, \& Hadjistavropoulos, 1993), and younger (<32 weeks PC) newborns' latencies of facial expression in response to a heel lance procedure are longer (R. Slater et al., 2009).

Procedures Comparisons between studies can be difficult due to the variety of stimuli used to assess similar abilities. Thus, auditory perception is studied by using different types of sound stimuli: from noise to tones or clicks or vibro-acoustic stimuli, once again independently of the fetus' or newborn's age (Hepper \& Shahidullah, 1994; Kisilevsky, Fearon, \& Muir, 1998; Kisilvesky \& Muir, 1991; Kuhn et al., 2012).

Overall, absence of reaction does not mean absence of perception. As mentioned above, sensory receptors are globally present from the first postconceptional weeks onward, so fetuses could be able to perceive stimuli relatively early during pregnancy. However, connections between sensory receptors and the brain become fully functional some time after their emergence. Thus, the withdrawal reaction observed after tactile stimulation of a 7-week-old PC fetus (Hooker, 1942) may well be a spinal cord reflex more than a reaction to a perception.

More generally, care must be taken before drawing any conclusion from a reaction or absence of reaction to a stimulation that the procedure and the measures chosen really address the question and that no underling process interferes with the observed response. For instance, failure to detect a preference between two stimuli should not lead to the conclusion that the infant cannot perceive a difference between them. Absence of preference does not necessarily mean absence of discrimination. Newborns may disengage from a detected stimuli only because it does not reach expectations related to their previous experience and knowledge (Aslin, 2007). The use of some behaviors to investigate newborns' sensory perception is now challenged, and a need for complementary, and often more detailed measures, has emerged. For example, gaze duration has been a major parameter used to assess many aspects of infants' perception and cognition. As questions become more complex, authors like Aslin (2007) plead for the development of new methods and more fine-grained evaluations (i.e. gaze duration, gaze patterns, direction of first look, frequency of switching).

Conclusion Studies of sensory reactions should address a large panel of parameters rather than a single one. Different types of reaction should be evaluated and associated with particular intrinsic (age, sex) and extrinsic factors (contexts). This integrative approach would enhance the robustness of the results.

\section{Perspectives and reflections}

This review updates our knowledge concerning newborns' umwelt, from the earliest development of fetuses' sensory systems to newborns' capacities to perceive and react to external stimulation during their first days of life. We show that newborns are able to perceive many sensory stimulations and that they can associate stimuli perceived through various sensory modalities (cross modality). We stress the fact that the level and the expression of reactions vary according to many intra- and extrinsic factors and that they must be taken into account before cautiously interpreting data. New methods need to be developed to enhance common physiological and current behavioral evaluations.

\section{Promoting quantitative behavioral observations}

Even the most premature newborns can express behavioral reactions. Numerous studies underline the fact that fetuses and premature and full-term newborns modify their behavior in reaction to sensory stimulations. For instance, as early as 19 weeks PC, fetuses are able to move in reaction to an 
auditory or a vibro-tactile stimulation through the maternal abdominal wall (Hepper \& Shahidullah, 1994; Leader et al., 1982). Twenty-three week-old PC newborns are able, like full-term newborns, to produce typical facial expressions (raise or lower brow, squeeze eyes, wrinkle nose, stretch lips; Gibbins et al., 2008; Grunau et al., 1990). Premature newborns can produce subtle movements of their extremities (finger extension) after a heel lance (Morison et al., 2003) and emit various types of vocalizations (Gaspardo et al., 2008; Johnston et al., 1993).

Behavioral responses are observed sometimes when no physiological changes can be evidenced. For example, premature newborns of less than 28 weeks PC modify their facial expressions after a blood sample procedure although no physiological changes (heart rate and oxygen saturation) are recorded (Gibbins et al., 2008). The delivery of a sweet solution during a painful procedure decreases negative facial expressions, although, again, no effects on heart rate or cortical activities are observed (Gaspardo et al., 2008; R. Slater et al., 2010). This indicates that appropriate behavioral approaches should be promoted in the future to improve the range of responses, including the subtlest responses, recorded after sensory stimulations.

So far, behavioral data such as facial expressions (Gibbins et al., 2008; Grunau et al., 1990), body movements (Durier et al., 2015; Morison et al., 2003), crying (Gaspardo et al., 2008; Owens \& Todt, 1984), gaze durations (Guellaï \& Streri, 2011), or head orientation (Schaal et al., 1998) have proved very useful to evaluate newborns' responses to different kinds of stimulation. However, quantitative behavioral evaluations are still lacking, although they would be a promising way to develop noninvasive methods to evaluate newborns' reactions to sensory stimulations. These evaluations should include the occurrence of numerous behavioral items, their duration, their temporal pattern of occurrence, their context and so on. The development of this behavioral approach would be a rigorous way to adapt and improve current methodologies and yield detailed data concerning newborns' sensory perception.

As mentioned previously, investigations should favor multimethodological approaches (behavior, physiology, hormones) in order to achieve a global assessment of newborns' sensory umwelt.

\section{Other biological models to highlight the long-term impact of early sensory stimulations}

Investigations of animal models help improve our understanding of human behavioral development; they create a fertile ground to elaborate new hypotheses and research directions. Animal studies can be a source of inspiration and awareness concerning the impact of inappropriate stimulations and handling procedures, especially as pertinent congruences between humans and other animals in very early life, have been underlined (Gottlieb \& Lickliter, 2004).

Animal models of early human development Two main models of development predominate in the literature. The first model, the "core knowledge theory" (Carey \& Spelke, 1996) considers the existence of at least four core systems for representing objects, actions, numbers, and space, while a fifth may correspond to the representation of social partners. This model proposes that each of these systems is deeply rooted in phylogeny. Indeed, studies of animals show that supposed human-specific abilities at birth can also be evidenced for other animal species. Thus, monkeys (Sugita, 2008) or chicks (Rosa Salva, Farroni, Regolin, Vallortigara, \& Johnson, 2011; Rosa Salva, Regolin, \& Vallortigara, 2010, 2012) can detect and discriminate faces. Newborns of several animal species show a preference for biological motion (monkeys: J. Brown, Kaplan, Rogers, \& Vallortigara, 2010; Miura \& Matsushima, 2012; fish: Nakayasu \& Watanabe, 2014; chicks: Rugani, Rosa Salva, Regolin, \& Vallortigara, 2015; Simion et al., 2008; Vallortigara, Regolin, \& Marconato, 2005) and animated objects (Rosa Salva, Mayer, \& Vallortigara, 2015; Vallortigara, 2012) as do human newborns (Bardi, Regolin, \& Simion, 2011; Di Giorgio, Lunghi, Simion, \& Vallortigara, 2016; Woodward, Phillips, \& Spelke, 1993). While this model emphasizes evolutionary history and its impact on human infants' early competencies, the other predominant model, the developmental psychobiological systems view, also called experiential canalization, with its bidirectional influences (Gottlieb, 1991), emphasizes the permanent reciprocal coactions of environmental and species-specific characteristics. This model and the first model are therefore complementary. According to Gottlieb (1991),

individual development is characterized by an increase of complexity of organization at all levels of analysis as a consequence of horizontal (same level coactions, i.e. gene-gene, tissue-tissue . . .) and vertical (between levels, i.e. behavior-environment . . .) co-actions among an organism's parts, including its environment.

This statement has two major implications. First, stimulations that embryos, fetuses, and then the young receive from their environment shape their behavioral development as much as their genetic background does. Second, sensory development and then sensory inputs of one modality can influence the sensory development of another modality.

This model emphasizes the importance of the sequential onset of sensory functions and its related sensory limitations during individual development (Gottlieb, 1971; Turkewitz \& Kenny, 1982), which has been confirmed by many animalbased investigations. Early sensory stimulations, at a stage when a modality is not normally stimulated, not only may 
not enhance abilities but in addition could have deleterious effects. For instance, abnormal visual stimulations of young mammals lead to impaired neuro-sensory development of the vision circuitry (e.g., rats: Borges \& Berry, 1978; cats: Hubel \& Wiesel, 1970; mice: Vistamehr \& Tian, 2004). From animal-based studies emerges the idea of an optimal range of stimulations. For instance, quail chicks' postnatal visual responsiveness is enhanced after moderate prenatal visual stimulation (Lickliter, 1990a), while a prolonged prenatal visual stimulation impairs visual development as for auditory development (Sleigh \& Lickliter, 1995). This could be most important to help improve nursing care procedures for preterm infants. Thus, skin-to-skin contacts have a significant effect decreasing salivary cortisol levels, and supposedly stress; the fact that massages produce more inconsistent effects (Gitau et al., 2002) could be explained by differences in strength of the tactile stimulations. Prenatal overstimulation, either visual or vestibular, of birds alters postnatal responsiveness to specific auditory stimuli, such as maternal vocalizations, and impairs hierarchical use or learning of another sensory input (quail: Lickliter, 1990b; Lickliter, 1994; Lickliter \& Hellewell, 1992; ducks: Radell \& Gottlieb, 1992). Senses are therefore interconnected very early during development, and intersensory interference may occur following a wrongly timed or wrongly proportioned stimulation, eliciting an impaired sensory and/or behavioral development.

This is especially important during the fetal stage as prenatal experiences of sensory stimulations are transmitted transnatally. For example, intrauterine exposure of rats to ethanol enhances self-administration after birth in operant conditioning experiments (Miranda-Morales, Nizhnikov, \& Spear, 2014). When pregnant rats are exposed to space flight conditions, the development of their fetuses' vestibular system is modified, suggesting that stimulation by maternal movements is a significant factor to be taken into consideration in studies of vestibular sensory development (Ronca, Fritzsch, Bruce, \& Alberts, 2008). More generally, prenatal stimulations can disrupt the organization of the developing brain (Mooney, Siegel, $\&$ Gest, 1985). Piglets are able to recognize a human voice heard during the sow's pregnancy. They appear distressed when that human voice was previously associated with a negative maternal emotional state during pregnancy (Tallet, Rakotomahandry, Guérin, Lemasson, \& Hausberger, 2016). Transnatal transmission has been demonstrated mainly for humans' chemical perception and, to some extent, for their auditory perception, but more information is still needed for both these modalities and others.

Laterality Laterality remains understudied both in terms of stimulation and reaction modality. Newborns' lateralized responses can yield information concerning their perception and brain processing of stimuli as shown by numerous animal studies (see a review in Rogers, 2014). A lateralized handling procedure at birth influences foals' subsequent emotional reactions in an approach/contact test; they differ in relation to body side stimulated previously (de Boyer des Roches et al., 2011). The authors hypothesized that sensitivity differed between bodysides inducing different emotional values associated with handling. Chicken embryos are oriented in the egg so that their right eye can receive external light through the shell. Incubation in the dark meaning lack of lateralized exposure to light leads to an absence of visual specialization of each hemisphere after hatching (Rogers, 2008). As mentioned above, only a few studies mention an impact of the side of sensory stimulations on newborns' responses (Hammer \& Turkewitz, 1974; Turkewitz et al., 1966). This aspect remains a promising path to explore both in terms of information concerning the sensory system and in terms of routine practices.

Several studies underline the impact of the first neonatal interactions/handling procedures on behavioral development (horses: Hausberger, Henry, Larose, \& Richard-Yris, 2007; rodents: Lehmann \& Feldon, 2000; Pryce et al., 2005). The routine procedure involving intensive tactile stimulations of horses just after birth induces long term disturbances and locomotor inhibition (Durier, Henry, Sankey, Sizun, \& Hausberger, 2012; Henry, Richard-Yris, Tordjman, \& Hausberger, 2009). Similarly, early postpartum routine practices could affect human newborns' sensory and emotional development.

\section{Implications for care of newborns}

In modern hospital services, at birth, newborn infants, particularly when premature, are suddenly confronted with a novel (potentially "aggressive") environment. Our current knowledge of sensory development highlights the importance of the environmental stimulations and the risk of interference created by wrong inputs (quality and/or intensity) or incorrect timing in neonatal intensive care units (NICU; Browne, 2011; Graven \& Browne, 2008). Over the past decades, increasingly more recommendations concerning the environment and nursing practices within NICU have aimed to decrease mismatches between the stimulations provided and the actual needs of the newborn in order to decrease mismatch between stimulations provided and the actual needs of the newborn (Blackburn, 1998; Graven, 2000; Liu et al., 2007; Long, Lucey, et al., 1980; Mann et al., 1986; Philbin, 2000; R. D. White, 2011a, 2011b). Still, goals concerning light and noise prove difficult to reach (Lasky \& Williams, 2009; Philbin, Lickliter, \& Graven, 2000) and assessments of positive or negative outcomes of different environmental conditions may be challenging (Laudert et al., 2007). However, a decrease of one or both of these stimulations for part of the day has at least a short-term impact on sleep regulation and 
weight gain (Mann et al., 1986; Rivkees et al., 2004). Adjustments of overall NICU practices and environmental conditions to the premature newborns' needs have proved to lead to better medical, neurodevelopmental, and social outcomes (Als et al., 2004; Als et al., 2003). To further improve the care of newborn infants, particularly in NICU, we must enhance our knowledge of fetuses' and infants' developmental processes, our assessment of environmental influences on the organization and maintenance of these processes and the quantification of the stimulations received by the infants from their caregiving environment (Philbin et al., 2000).

Author note The idea of this review emerged from scientific discussions among members of an interdisciplinary research project (Groupement d'Intérêt Scientifique "Cerveau-Comportement-Société"/ Scientific Interest Group "Brain-Behavior-Society"). This study received financial support from the French Ministry of Research and the CNRS. We thank Jacques Sizun and Alain Beuchée for their medical contribution and Marianne Barbu-Roth for her bibliography input. We are very grateful to Ann Cloarec and Jodi Pawluski for checking and correcting the English.

\section{References}

Abramov, I., Gordon, J., Hendrickson, A., Hainline, L., Dobson, V., \& LaBossiere, E. (1982). The retina of the newborn human infant. Science, 217(4556), 265-267. doi:10.1126/science.6178160

Adams, R. J., Courage, M. L., \& Mercer, M. E. (1991). Deficiencies in human neonates' color vision: Photoreceptoral and neural explanations. Behavioural Brain Research, 43(2), 109-114. doi:10.1016/ S0166-4328(05)80060-9

Adams, R. J., Courage, M. L., \& Mercer, M. E. (1994). Systematic measurement of human neonatal color vision. Vision Research, 34(13), 1691-1701. doi:10.1016/0042-6989(94)90127-9

Adams, R. J., Maurer, D., \& Cashin, H. A. (1990). The influence of stimulus size on newborns' discrimination of chromatic from achromatic stimuli. Vision Research, 30(12), 2023-2030. doi:10.1016/ 0042-6989(90)90018-G

Adams, R. J., Maurer, D., \& Davis, M. (1986). Newborns' discrimination of chromatic from achromatic stimuli. Journal of Experimental Child Psychology, 41(2), 267-281. doi:10.1016/0022-0965(86) 90040-8

Aladjem, S., Feria, A., Rest, J., \& Stojanovic, J. (1977). Fetal heart rate responses to fetal movements. BJOG: An International Journal of Obstetrics \& Gynaecology, 84(7), 487-491. doi:10.1111/j.14710528.1977.tb12630.x

Alberts, J. R. (2008). The nature of nurturant niches in ontogeny. Philosophical Psychology, 21(3), 295-303. doi:10.1080/ 09515080802169814

Alberts, J. R., \& Cramer, C. P. (1988). Ecology and experience. In E. M. Blass (Ed.), Developmental psychobiology and behavioral ecology (pp. 1-39). Boston, MA: Springer US.

Alberts, J. R., \& Harshaw, C. (2014). Behavioral development and ontogenetic adaptation. In K. Yasukawa \& Z. Tang-Martinez (Eds.), Animal behavior: How and why animals do the things they do (Vol. 1, pp. 289-324). Santa Barbara, CA: Praeger.

Alberts, J. R., \& Ronca, A. E. (1993). Fetal experience revealed by rats: Psychobiological insights. Early Human Development, 35(3), 153166. doi:10.1016/0378-3782(93)90102-Z
Allen, M. C., \& Capute, A. J. (1986). Assessment of early auditory and visual abilities of extremely premature infants. Developmental Medicine \& Child Neurology, 28(4), 458-466. doi:10.1111/j.14698749.1986.tb14283.x

Als, H., Duffy, F. H., McAnulty, G. B., Rivkin, M. J., Vajapeyam, S., Mulkern, R. V., ... Eichenwald, E. C. (2004). Early experience alters brain function and structure. Pediatrics, 113(4), 846-857.

Als, H., Gilkerson, L., Duffy, F. H., Mcanulty, G. B., Buehler, D. M., Vandenberg, K., ... Jones, K. J. (2003). A three-center, randomized, controlled trial of individualized developmental care for very low birth weight preterm infants: Medical, neurodevelopmental, parenting, and caregiving effects. Journal of Developmental \& Behavioral Pediatrics, 24(6), 399-408.

Anand, K. J., \& Hickey, P. R. (1987). Pain and its effects in the human neonate and fetus. New England Journal of Medicine, 317(21), 1321-1329. doi:10.1056/NEJM198711193172105

Ando, Y., \& Hattori, H. (1970). Effects of intense noise during fetal life upon postnatal adaptability (Statistical study of the reactions of babies to aircraft noise). The Journal of the Acoustical Society of America, 47(4B), 1128-1130. doi:10.1121/1.1912014

Antell, S. E., \& Keating, D. P. (1983). Perception of numerical invariance in neonates. Child Development, 54(3), 695-701. doi:10.2307/ 1130057

Arabin, B., Geinbruch, U., \& von Eyck, J. (1993). Registration of fetal behaviour in multiple pregnancy. Journal of Perinatal Medicine, 21(4), 285-294. doi:10.1515/jpme.1993.21.4.285

Aslin, R. N. (2007). What's in a look? Developmental Science, 10(1), 48 53. doi:10.1111/j.1467-7687.2007.00563.x

Badalian, S. S., Chao, C. R., Fox, H. E., \& Timor-Tritsch, I. E. (1993). Fetal breathing - Related nasal fluid flow velocity in uncomplicated pregnancies. American Journal of Obstetrics and Gynecology, 169(3), 563-567. doi:10.1016/0002-9378(93)90621-O

Ball, W., \& Tronick, E. (1971). Infant responses to impending collision: Optical and real. Science, 171(3973), 818-820. doi:10.1126/science. 171.3973 .818

Barbu-Roth, M., Anderson, D. I., Desprès, A., Provasi, J., Cabrol, D., \& Campos, J. J. (2009). Neonatal stepping in relation to terrestrial optic flow. Child Development, 80(1), 8-14. doi:10.1111/j.1467-8624. 2008.01241.x

Barbu-Roth, M., Anderson, D. I., Desprès, A., Streeter, R. J., Cabrol, D., Trujillo, M., ... Provasi, J. (2014). Air stepping in response to optic flows that move toward and away from the neonate. Developmental Psychobiology, 56(5), 1142-1149. doi:10.1002/dev.21174

Bardi, L., Regolin, L., \& Simion, F. (2011). Biological motion preference in humans at birth: Role of dynamic and configural properties. Developmental Science, 14(2), 353-359. doi:10.1111/j.1467-7687. 2010.00985.x

Bartocci, M., Winberg, J., Papendieck, G., Mustica, T., Serra, G., \& Lagercrantz, H. (2001). Cerebral hemodynamic response to unpleasant odors in the preterm newborn measured by near-infrared spectroscopy. Pediatric Research, 50(3), 324-330. doi:10.1203/ 00006450-200109000-00006

Bartocci, M., Winberg, J., Ruggiero, C., Bergqvist, L. L., Serra, G., \& Lagercrantz, H. (2000). Activation of olfactory cortex in newborn infants after odor stimulation: A functional near-infrared spectroscopy study. Pediatric Research, 48(1), 18-23. doi:10.1203/ 00006450-200007000-00006

Bell, A. F., White-Traut, R., Wang, E. C., \& Schwertz, D. (2012). Maternal and umbilical artery cortisol at birth: Relationships with epidural analgesia and newborn alertness. Biological Research for Nursing, 14(3). doi:10.1177/1099800411413460

Benzaquen, S., Gagnon, R., Hunse, C., \& Foreman, J. (1990). The intrauterine sound environment of the human fetus during labor. American Journal of Obstetrics and Gynecology, 163(2), 484-490. doi:10.1016/0002-9378(90)91180-K 
Bertelle, V., Mabin, D., Adrien, J., \& Sizun, J. (2005). Sleep of preterm neonates under developmental care or regular environmental conditions. Early Human Development, 81(7), 595-600. doi:10.1016/j. earlhumdev.2005.01.008

Bertoncini, J., Bijeljac-Babic, R., Blumstein, S. E., \& Mehler, J. (1987). Discrimination in neonates of very short CVs. The Journal of the Acoustical Society of America, 82(1), 31-37. doi:10.1121/1.395570

Bertoncini, J., Morais, J., Bijeljac-Babic, R., McAdams, S., Peretz, I., \& Mehler, J. (1989). Dichotic perception and laterality in neonates. Brain and Language, 37(4), 591-605. doi:10.1016/0093-934X(89) 90113-2

Bidet-Ildei, C., Kitromilides, E., Orliaguet, J.-P., Pavlova, M., \& Gentaz, E. (2014). Preference for point-light human biological motion in newborns: Contribution of translational displacement. Developmental Psychology, 50(1), 113-120. doi:10.1037/a0032956

Bijeljac-Babic, R., Bertoncini, J., \& Mehler, J. (1993). How do 4-day-old infants categorize multisyllabic utterances? Developmental Psychology, 29(4), 711-721. doi:10.1037/0012-1649.29.4.711

Blackburn, S. (1998). Environmental impact of the NICU on developmental outcomes. Journal of Pediatric Nursing, 13(5), 279-289. doi:10.1016/S0882-5963(98)80013-4

Borges, S., \& Berry, M. (1978). The effects of dark rearing on the development of the visual cortex of the rat. The Journal of Comparative Neurology, 180(2), 277-300. doi:10.1002/cne.901800207

Bossy, J. (1980). Development of olfactory and related structures in staged human embryos. Anatomy and Embryology, 161, 225-236. doi:10.1007/BF00305346

Bradfield, A. (1961). The Vagal Factor in Foetal Heart Rate Change IThe effect of abdominal pressure. Australian and New Zealand Journal of Obstetrics and Gynaecology, 1(3), 106-112. doi:10. 1111/j.1479-828X.1961.tb00089.x

Bradley, R. M., \& Stern, I. B. (1967). The development of the human taste bud during the foetal period. Journal of Anatomy, 101(Pt. 4), 743 752 .

Brown, J., Kaplan, G., Rogers, L. J., \& Vallortigara, G. (2010). Perception of biological motion in common marmosets (Callithrix jacchus): By females only. Animal Cognition, 13(3), 555-564. doi:10.1007/ s10071-009-0306-0

Brown, A. M., Lindsey, D. T., Cammenga, J. G., Giannone, P. J., \& Stenger, M. R. (2015). The contrast sensitivity of the newborn human infant. Investigative Ophthalmology \& Visual Science, 56, 625632. doi:10.1167/iovs.14-14757

Browne, J. V. (2008). Chemosensory development in the fetus and newborn. Newborn and Infant Nursing Reviews, 8(4), 180-186. doi:10. 1053/j.nainr.2008.10.009

Browne, J. V. (2011). Developmental Care for High-Risk Newborns: Emerging science, clinical application, and continuity from newborn intensive care unit to community. Clinics in Perinatology, 38(4), 719-729. doi:10.1016/j.clp.2011.08.003

Burkhalter, A., Bernardo, K. L., \& Charles, V. (1993). Development of local circuits in human visual cortex. The Journal of Neuroscience, 13(5), 1916-1931.

Bystrova, K., Widström, A. M., Matthiesen, A. S., Ransjö-Arvidson, A. B., Welles-Nyström, B., Wassberg, C., ... Uvnäs-Moberg, K. (2003). Skin-to-skin contact may reduce negative consequences of "the stress of being born": A study on temperature in newborn infants, subjected to different ward routines in St. Petersburg. Acta Pcediatrica, 92(3), 320-326. doi:10.1111/j.1651-2227.2003. tb00553.x

Carey, S., \& Spelke, E. (1996). Science and core knowledge. Philosophy of Science, 63(4), 515-533. doi:10.1086/289971

Cassidy, J. W., \& Ditty, K. M. (2001). Gender differences among newborns on a transient otoacoustic emissions test for hearing. Journal of Music Therapy, 38, 28-35. doi:10.1093/jmt/38.1.28

Cheour-Luhtanen, M., Alho, K., Sainio, K., Rinne, T., Reinikainen, K., Pohjavuori, M., ... Näätänen, R. (1996). The ontogenetically earliest discriminative response of the human brain. Psychophysiology, 33(4), 478-481. doi:10.1111/j.1469-8986.1996.tb01074.x

Chin, K. C., Taylor, M. J., Menzies, R., \& Whyte, H. (1985). Development of visual evoked potentials in neonates. A study using light emitting diode goggles. Archives of Disease in Childhood, 60, 1166-1168. doi:10.1136/adc.60.12.1166

Chuah, M. I., \& Zheng, D. R. (1987). Olfactory marker protein is present in olfactory receptor cells of human fetuses. Neuroscience, 23(1), 363-370. doi:10.1016/0306-4522(87)90296-X

Clairambault, J., Curzi-Dascalova, L., Kauffmann, F., Médigue, C., \& Leffler, C. (1992). Heart rate variability in normal sleeping fullterm and preterm neonates. Early Human Development, 28(2), 169-183. doi:10.1016/0378-3782(92)90111-S

Coulon, M., Guellaï, B., \& Streri, A. (2011). Recognition of unfamiliar talking faces at birth. International Journal of Behavioral Development. doi:10.1177/0165025410396765

Coulon, M., Hemimou, C., \& Streri, A. (2013). Effects of seeing and hearing vowels on neonatal facial imitation. Infancy, 18(5), 782796. doi:10.1111/infa.12001

Craig, K. D. (1992). The facial expression of pain Better than a thousand words? APS Journal, 1, 153-162. doi:10.1016/1058-9139(92) 90001-S

Craig, K. D., Whitfield, M. F., Grunau, R. V. E., Linton, J., \& Hadjistavropoulos, H. D. (1993). Pain in the preterm neonate: Behavioural and physiological indices. Pain, 52(3), 287-299. doi: 10.1016/0304-3959(93)90162-I

Crook, C. K. (1978). Taste perception in the newborn infant. Infant Behavior and Development, 1, 52-69. doi:10.1016/S01636383(78)80009-5

Curzi-Dascalova, L., Lebrun, F., \& Korn, G. (1983). Respiratory frequency according to sleep states and age in normal premature infants: A comparison with full term infants. Pediatric Research, 17(2), 152156. doi:10.1203/00006450-198302000-00014

Curzi-Dascalova, L., Peirano, P., \& Morel-Kahn, F. (1988). Development of sleep states in normal premature and full-term newborns. Developmental Psychobiology, 21(5), 431-444. doi:10.1002/dev. 420210503

Darcy, A. E., Hancock, L. E., \& Ware, E. J. (2008). A descriptive study of noise in the neonatal intensive care unit ambient levels and perceptions of contributing factors. Advances in Neonatal Care, 8(3), 165175. doi:10.1097/01.ANC.0000324341.24841.6e

Davis, E. P., Glynn, L. M., Waffarn, F., \& Sandman, C. A. (2011). Prenatal maternal stress programs infant stress regulation. Journal of Child Psychology and Psychiatry, 52(2), 119-129. doi:10.1111/j. 1469-7610.2010.02314.x

de Boyer des Roches, A., Durier, V., Richard-Yris, M.-A., Blois-Heulin, C., Ezzaouia, M., Hausberger, M., \& Henry, S. (2011). Differential outcomes of unilateral interferences at birth. Biology Letters, 7(2), 177-180. doi:10.1098/rsbl.2010.0979

de Vries, J. I. P., Visser, G. H. A., \& Prechtl, H. F. R. (1985). The emergence of fetal behaviour: II. Quantitative aspects. Early Human Development, gil2(2), 99-120. doi:10.1016/0378-3782(85)90174-4

Debillon, T., Gras-Leguen, C., Boscher, C., \& Fleury, M. A. (1998). Les grilles d'évaluation de la douleur chez le nouveau-né: Revue de la litterature. [The grids for the evaluation of pain in the newborn: Review of the literature]. Douleur et Analgésie, 11(4), 167-172. doi: 10.1007/BF03013831

DeCasper, A. J., \& Fifer, W. P. (1980). Of human bonding: Newborns prefer their mothers' voices. Science, 208(4448), 1174-1176. doi: 10.1126/science. 7375928

DeCasper, A. J., \& Spence, M. J. (1986). Prenatal maternal speech influences newborns' perception of speech sounds. Infant Behavior and Development, 9(2), 133-150. doi:10.1016/0163-6383(86)90025-1

Del Giudice, M. (2011). Alone in the dark? Modeling the conditions for visual experience in human fetuses. Developmental Psychobiology, 53(2), 214-219. doi:10.1002/dev.20506 
Delaunay-El Allam, M., Marlier, L., \& Schaal, B. (2006). Learning at the breast: Preference formation for an artificial scent and its attraction against the odor of maternal milk. Infant Behavior and Development, 29(3), 308-321. doi:10.1016/j.infbeh.2005.12.008

Desor, J. A., Maller, O., \& Andrews, K. (1975). Ingestive responses of human newborns to salty, sour, and bitter stimuli. Journal of Comparative and Physiological Psychology, 89(8), 966-970. doi: 10.1037/h0077171

Di Giorgio, E., Leo, I., Pascalis, O., \& Simion, F. (2012). Is the faceperception system human-specific at birth? Developmental Psychology, 48(4), 1083-1090. doi:10.1037/a0026521

Di Giorgio, E., Lunghi, M., Simion, F., \& Vallortigara, G. (2016). Visual cues of motion that trigger animacy perception at birth: The case of self-propulsion. Developmental Science. doi:10.1111/desc.12394

DiPietro, J. A., Costigan, K. A., \& Gurewitsch, E. D. (2003). Fetal response to induced maternal stress. Early Human Development, 74(2), 125-138. doi:10.1016/j.earlhumdev.2003.07.001

DiPietro, J. A., Kivlighan, K. T., Costigan, K. A., \& Laudenslager, M. L. (2009). Fetal motor activity and maternal cortisol. Developmental Psychobiology, 51(6), 505-512. doi:10.1002/dev.20389

Doucet, S., Soussignan, R., Sagot, P., \& Schaal, B. (2009). The secretion of areolar (Montgomery's) glands from lactating women elicits selective, unconditional responses in neonates. PLoS ONE, 4(10), e7579. doi:10.1371/journal.pone.0007579

Draganova, R., Eswaran, H., Murphy, P., Huotilainen, M., Lowery, C., \& Preissl, H. (2005). Sound frequency change detection in fetuses and newborns, a magnetoencephalographic study. Neurolmage, 28(2), 354-361. doi:10.1016/j.neuroimage.2005.06.011

Dunkeld, J., \& Bower, T. G. R. (1980). Infant response to impending optical collision. Perception, 9(5), 549-554. doi:10.1068/p090549

Durier, V., Henry, S., Martin, E., Dollion, N., Hausberger, M., \& Sizun, J. (2015). Unexpected behavioural consequences of preterm newborns' clothing. Scientific Reports, 5. doi:10.1038/srep09177

Durier, V., Henry, S., Sankey, C., Sizun, J., \& Hausberger, M. (2012). Locomotor inhibition in adult horses faced to stressors: A single postpartum experience may be enough! Comparative Psychology, 3, 442. doi:10.3389/fpsyg.2012.00442

Eiselt, M., Curzi-Dascalova, L., Clairambault, J., Kauffmann, F., Médigue, C., \& Peirano, P. (1993). Heart-rate variability in lowrisk prematurely born infants reaching normal term: A comparison with full-term newborns. Early Human Development, 32(2/3), 183195. doi:10.1016/0378-3782(93)90011-I

Emory, E. K., Schlackman, L. J., \& Fiano, K. (1996). Drug-hormone interactions on neurobehavioral responses in human neonates. Infant Behavior and Development, 19(2), 213-220. doi:10.1016/ S0163-6383(96)90020-X

Fabrizi, L., Slater, R., Worley, A., Meek, J., Boyd, S., Olhede, S., \& Fitzgerald, M. (2011). A shift in sensory processing that enables the developing human brain to discriminate touch from pain. Current Biology, 21(18), 1552-1558. doi:10.1016/j.cub.2011.08. 010

Fantz, R. L. (1963). Pattern vision in newborn infants. Science, 140(3564), 296-297. doi:10.1126/science.140.3564.296

Farroni, T., Csibra, G., Simion, F., \& Johnson, M. H. (2002). Eye contact detection in humans from birth. Proceedings of the National Academy of Sciences, 99(14), 9602-9605. doi:10.1073/pnas. 152159999

Farroni, T., Johnson, M. H., Menon, E., Zulian, L., Faraguna, D., \& Csibra, G. (2005). Newborns' preference for face-relevant stimuli: Effects of contrast polarity. Proceedings of the National Academy of Sciences of the United States of America, 102(47), 17245-17250. doi:10.1073/pnas.0502205102

Feldman, R., \& Eidelman, A. I. (2003). Skin-to-skin contact (Kangaroo Care) accelerates autonomic and neurobehavioural maturation in preterm infants. Developmental Medicine \& Child Neurology, 45(4), 274-281. doi:10.1111/j.1469-8749.2003.tb00343.x
Ferber, S. G., \& Makhoul, I. R. (2004). The effect of skin-to-skin contact (Kangaroo Care) shortly after birth on the neurobehavioral responses of the term newborn: A randomized, controlled trial. Pediatrics, 113(4), 858-865. doi:10.1542/peds.113.4.858

Forslund, M., \& Bjerre, I. (1983). Neurological assessment of preterm infants at term conceptional age in comparison with normal full-term infants. Early Human Development, 8(3-4), 195-208. doi:10.1016/ 0378-3782(83)90002-6

Friedman, S., Bruno, L. A., \& Vietze, P. (1974). Newborn habituation to visual stimuli: A sex difference in novelty detection. Journal of Experimental Child Psychology, 18(2), 242-251. doi:10.1016/ 0022-0965(74)90104-0

Fulford, J., Vadeyar, S. H., Dodampahala, S. H., Moore, R. J., Young, P., Baker, P. N., ... Gowland, P. A. (2003). Fetal brain activity in response to a visual stimulus. Human Brain Mapping, 20(4), 239245. doi:10.1002/hbm.10139

Fulford, J., Vadeyar, S. H., Dodampahala, S. H., Ong, S., Moore, R. J., Baker, P. N., ... Gowland, P. (2004). Fetal brain activity and hemodynamic response to a vibroacoustic stimulus. Human Brain Mapping, 22(2), 116-121. doi:10.1002/hbm.20019

Ganchrow, J. R., Steiner, J. E., \& Daher, M. (1983). Neonatal facial expressions in response to different qualities and intensities of gustatory stimuli. Infant Behavior and Development, 6(2-3), 189-200. doi:10.1016/S0163-6383(83)80026-5

Gaspardo, C. M., Miyase, C. I., Chimello, J. T., Martinez, F. E., \& Martins Linhares, M. B. (2008). Is pain relief equally efficacious and free of side effects with repeated doses of oral sucrose in preterm neonates? Pain, 137(1), 16-25. doi:10.1016/j.pain.2007.07.032

Gauthaman, G., Jayachandran, L., \& Prabhakar, K. (1984). Olfactory reflexes in newborn infants. The Indian Journal of Pediatrics, 51(4), 397-399. doi:10.1007/bf02776422

Gerhardt, K. J., \& Abrams, R. M. (1996). Fetal hearing: Characterization of the stimulus and response. Seminars in Perinatology, 20(1), 1120. doi:10.1016/S0146-0005(96)80053-X

Giannakoulopoulos, X., Glover, V., Sepulveda, W., Kourtis, P., \& Fisk, N. M. (1994). Fetal plasma cortisol and $\beta$-endorphin response to intrauterine needling. The Lancet, 344(8915), 77-81. doi:10.1016/ S0140-6736(94)91279-3

Gibbins, S., Stevens, B., McGrath, P. J., Yamada, J., Beyene, J., Breau, L., ... Ohlsson, A. (2008). Comparison of pain responses in infants of different gestational ages. Neonatology, 93(1), 10-18. doi:10.1159/ 000105520

Gitau, R., Modi, N., Gianakoulopoulos, X., Bond, C., Glover, V., \& Stevenson, J. (2002). Acute effects of maternal skin-to-skin contact and massage on saliva cortisol in preterm babies. Journal of Reproductive and Infant Psychology, 20(2), 83-88. doi:10.1080/ 02646830220134595

Glover, V., \& Fisk, N. M. (1999). Fetal pain: Implications for research and practice. BJOG: An International Journal of Obstetrics \& Gynaecology, 106(9), 881-886. doi:10.1111/j.1471-0528.1999. tb08424.x

Gottlieb, G. (1968). Prenatal behavior of birds. The Quarterly Review of Biology, 43(2), 148-174.

Gottlieb, G. (1971). Ontogenesis of sensory function in birds and mammals. In E. Tobach, L. R. Aronson, \& E. Shaw (Eds.), The biopsychology of development (pp. 67-128). New York, NY: Academic Press.

Gottlieb, G. (1991). Experiential canalization of behavioral development: Theory. Developmental Psychology, 27(1), 4-13.

Gottlieb, G., \& Lickliter, R. (2004). The various roles of animal models in understanding human development. Social Development, 13(2), 311-325. doi:10.1111/j.1467-9507.2004.000269.x

Goubet, N., Rattaz, C., Pierrat, V., Allémann, E., Bullinger, A., \& Lequien, P. (2002). Olfactory familiarization and discrimination in preterm and full-term newborns. Infancy, 3(1), 53-75. doi:10.1207/ s15327078in0301_3 
Goubet, N., Rattaz, C., Pierrat, V., Bullinger, A., \& Lequien, P. (2003). Olfactory experience mediates response to pain in preterm newborns. Developmental Psychobiology, 42(2), 171-180. doi:10.1002/dev.10085

Graven, S. N. (2000). Sound and the developing infant in the NICU: Conclusions and recommendations for care. Journal of Perinatology, 20 (8 Pt. 2), S88-S593.

Graven, S. N., \& Browne, J. V. (2008). Sensory development in the fetus, neonate, and infant: Introduction and overview. Newborn and Infant Nursing Reviews, 8(4), 169-172. doi:10.1053/j.nainr.2008.10.007

Gray, L., Watt, L., \& Blass, E. M. (2000). Skin-to-skin contact is analgesic in healthy newborns. Pediatrics, 105(1), e14.

Grunau, R. E., \& Craig, K. D. (1987). Pain expression in neonates: Facial action and cry. Pain, 28(3), 395-410. doi:10.1016/0304-3959(87) 90073-X

Grunau, R. E., Holsti, L., \& Peters, J. W. B. (2006). Long-term consequences of pain in human neonates. Seminars in Fetal and Neonatal Medicine, 11(4), 268-275. doi:10.1016/j.siny.2006.02.007

Grunau, R. E., Johnston, C. C., \& Craig, K. D. (1990). Neonatal facial and cry responses to invasive and non-invasive procedures. Pain, 42(3), 295-305. doi:10.1016/0304-3959(90)91142-6

Guellaï, B., Coulon, M., \& Streri, A. (2011). The role of motion and speech in face recognition at birth. Visual Cognition, 19(9), 12121233. doi: $10.1080 / 13506285.2011 .620578$

Guellaï, B., \& Streri, A. (2011). Cues for Early Social Skills: Direct gaze modulates newborns' recognition of talking faces. PLoS ONE, 6(4), e18610. doi:10.1371/journal.pone.0018610

Guinsburg, R., Fernanda, M., Almeida, B., Perez, C. A., Balda, R. C. X., Berenguel, R. C., ... Kopelman, B. I. (1999). Differences in pain expression between male and female newborn infants. Pediatric Research, 45(4, Pt. 2 of 2), 200A-200A. doi:10.1203/00006450199904020-01188

Hahn, W. K. (1987). Cerebral lateralization of function: From infancy through childhood. Psychological Bulletin, 101(3), 376-392. doi: 10.1037/0033-2909.101.3.376

Hall, J. R. (2000). Development of the ear and hearing. Journal of Perinatology: Official Journal of the California Perinatal Association, 20(8, Pt. 2), S12-S20.

Hammer, M., \& Turkewitz, G. (1974). A sensory basis for the lateral difference in the newborn infant's response to somesthetic stimulation. Journal of Experimental Child Psychology, 18(2), 304-312. doi:10.1016/0022-0965(74)90110-6

Hamon, I. (1996). Voies anatomiques de la douleur chez le nouveau-né prématuré. [Anatomical pathways of pain in preterm infants]. Archives de Pédiatrie, 3(10), 1006-1012. doi: 10.1016/0929693X(96)81724-6

Harrison, D., Boyce, S., Loughnan, P., Dargaville, P., Storm, H., \& Johnston, L. (2006). Skin conductance as a measure of pain and stress in hospitalised infants. Early Human Development, 82(9), 603-608. doi:10.1016/j.earlhumdev.2005.12.008

Hausberger, M., Henry, S., Larose, C., \& Richard-Yris, M.-A. (2007). First suckling: A crucial event for mother-young attachment? An experimental study in horses (Equus caballus). Journal of Comparative Psychology, 121(1), 109-112. doi:10.1037/07357036.121.1.109

Haynes, H., White, B. L., \& Held, R. (1965). Visual accommodation in human infants. Science, 148(3669), 528-530. doi:10.1126/science. 148.3669 .528

Hendrickson, A., \& Drucker, D. (1992). The development of parafoveal and mid-peripheral human retina. Behavioural Brain Research, 49(1), 21-31. doi:10.1016/S0166-4328(05)80191-3

Henry, S., Richard-Yris, M. A., Tordjman, S., \& Hausberger, M. (2009). Neonatal handling affects durably bonding and social development. PLoS ONE, 4(4), e5216. doi:10.1371/journal.pone.0005216

Hepper, P. G., \& Shahidullah, B. S. (1994). The development of fetal hearing. Fetal and Maternal Medicine Review, 6(03), 167-179. doi:10.1017/S0965539500001108
Hepper, P. G., Shahidullah, S., \& White, R. (1991). Handedness in the human fetus. Neuropsychologia, 29(11), 1107-1111. doi:10.1016/ 0028-3932(91)90080-R

Hernandez-Reif, M., Field, T., Diego, M., \& Largie, S. (2001). Weight perception by newborns of depressed versus non-depressed mothers. Infant Behavior and Development, 24(3), 305-316. doi: 10.1016/S0163-6383(01)00081-9

Hersch, M., \& Ganchrow, D. (1980). Scanning electron microscopy of developing papillae on the tongue of human embryos and fetuses. Chemical Senses, 5(4), 331-341. doi:10.1093/ chemse/5.4.331

Holditch-Davis, D., Scher, M., Schwartz, T., \& Hudson-Barr, D. (2004). Sleeping and waking state development in preterm infants. Early Human Development, 80(1), 43-64. doi:10.1016/j.earlhumdev. 2004.05.006

Hooker, D. (1942). Fetal reflexes and instinctual processes. Psychosomatic Medicine, 4(2), 199-205.

Hooker, D. (1952). The prenatal origin of behavior. Lawrence: University of Kansas Press.

Hubel, D. H., \& Wiesel, T. N. (1970). The period of susceptibility to the physiological effects of unilateral eye closure in kittens. The Journal of Physiology, 206(2), 419-436.

Humphrey, T. (1970). Reflex activity in the oral and facial area of the human fetus. In J. F. Bosma (Ed.), Second symposium on oral sensation and perception. Springfield, IL: Thomas.

Humphrey, T. (1978). Function of the nervous system during prenatal life. In U. Stave (Ed.), Perinatal physiology (pp. 651-683). Boston, MA: Springer US.

Hykin, J., Moore, R., Duncan, K., Clare, S., Baker, P., Johnson, I., ... Gowland, P. (1999). Fetal brain activity demonstrated by functional magnetic resonance imaging. The Lancet, 354(9179), 645-646. doi: 10.1016/S0140-6736(99)02901-3

Issel, E. P. (1983). Fetal response to external mechanical stimuli. Journal of Perinatal Medicine, 11(5), 232-242. doi:10.1515/jpme.1983.11. 5.232

Jaldo-Alba, F., Muñóz-Hoyos, A., Molina-Carballo, A., Molina-Font, J. A., \& Acuña-Castroviejo, D. (1993). Light deprivation increases plasma levels of melatonin during the first $72 \mathrm{~h}$ of life in human infants. Acta Endocrinologica, 129(5), 442-445. doi:10.1530/acta. 0.1290442

James, D. K., Spencer, C. J., \& Stepsis, B. W. (2002). Fetal learning: A prospective randomized controlled study. Ultrasound in Obstetrics and Gynecology, 20(5), 431-438. doi:10.1046/j.1469-0705.2002. 00845.x

Jandó, G., Mikó-Baráth, E., Markó, K., Hollódy, K., Török, B., \& Kovacs, I. (2012). Early-onset binocularity in preterm infants reveals experience-dependent visual development in humans. Proceedings of the National Academy of Sciences, 109(27), 11049-11052. doi:10.1073/pnas.1203096109

Johnston, C. C., Stevens, B., Craig, K. D., \& Grunau, R. V. E. (1993). Developmental changes in pain expression in premature, full-term, two- and four-month-old infants. Pain, 52(2), 201-208. doi:10. 1016/0304-3959(93)90132-9

Johnston, C. C., Stevens, B. J., Yang, F., \& Horton, L. (1995). Differential response to pain by very premature neonates. Pain, 61(3), 471-479. doi:10.1016/0304-3959(94)00213-X

Joseph, J. P., Lesevre, N., \& Dreyfus-Brisac, C. (1976). Spatio-temporal organization of EEG in premature infants and full-term new-borns. Electroencephalography and Clinical Neurophysiology, 40(2), 153168. doi:10.1016/0013-4694(76)90160-7

Kawakami, K., Takai-Kawakami, K., Masuda, N., Suzuki, M., Shimizu, Y., \& Yanaihara, T. (2002). Measuring human fetal responses to sounds by umbilical and middle-cerebral artery velocity waveforms: A preliminary study. Research and Clinical Center for Child Development, Annual Report, 24, 25-33. 
Kenner, C., \& Lubbe, W. (2007). Fetal stimulation-A preventative therapy. Newborn and Infant Nursing Reviews, 7(4), 227-230. doi:10. 1053/j.nainr.2007.06.013

Kisilevsky, B. S., Fearon, I., \& Muir, D. W. (1998). Fetuses differentiate vibroacoustic stimuli. Infant Behavior and Development, 21(1), 25 46. doi:10.1016/S0163-6383(98)90053-4

Kisilevsky, B. S., \& Hains, S. M. J. (2011). Onset and maturation of fetal heart rate response to the mother's voice over late gestation. Developmental Science, 14(2), 214-223. doi:10.1111/j.1467-7687. 2010.00970.x

Kisilevsky, B. S., Hains, S. M. J., Brown, C. A., Lee, C. T., Cowperthwaite, B., Stutzman, S. S., ... Wang, Z. (2009). Fetal sensitivity to properties of maternal speech and language. Infant Behavior and Development, 32(1), 59-71. doi:10.1016/j.infbeh. 2008.10.002

Kisilevsky, B. S., Pang, L., \& Hains, S. M. J. (2000). Maturation of human fetal responses to airborne sound in low- and high-risk fetuses. Early Human Development, 58(3), 179-195. doi:10.1016/ S0378-3782(00)00075-X

Kisilvesky, B. S., \& Muir, D. W. (1991). Human fetal and subsequent newborn responses to sound and vibration. Infant Behavior and Development, 14(1), 1-26. doi:10.1016/0163-6383(91)90051-S

Kiuchi, M., Nagata, N., Ikeno, S., \& Terakawa, N. (2000). The relationship between the response to external light stimulation and behavioral states in the human fetus: How it differs from vibroacoustic stimulation. Early Human Development, 58(2), 153-165. doi:10. 1016/S0378-3782(00)00074-8

Kuhn, P., Zores, C., Pebayle, T., Hoeft, A., Langlet, C., Escande, B., ... Dufour, A. (2012). Infants born very preterm react to variations of the acoustic environment in their incubator from a minimum signalto-noise ratio threshold of 5 to $10 \mathrm{dBA}$. Pediatric Research, 71(4/1), 386-392. doi:10.1038/pr.2011.76

Laquerrière, A. (2010). Mise en place des voies de la douleur chez le fœtus. [Implementation of pathways of pain in the fetus]. Médecine Thérapeutique/Médecine de la Reproduction, Gynécologie et Endocrinologie, 12(2), 111-115. doi: 10.1684/mte. 2010.0285

Lasky, R. E., \& Williams, A. L. (2009). Noise and Light exposures for extremely low birth weight newborns during their stay in the neonatal intensive care unit. Pediatrics, 123(2), 540-546. doi:10.1542/ peds.2007-3418

Laudert, S., Liu, W. F., Blackington, S., Perkins, B., Martin, S., MacMillan-York, E., ... Handyside, J. (2007). Implementing potentially better practices to support the neurodevelopment of infants in the NICU. Journal of Perinatalogy, 27(S2), S75-S93.

Lawn, J. E., Mwansa-Kambafwile, J., Horta, B. L., Barros, F. C., \& Cousens, S. (2010). 'Kangaroo mother care' to prevent neonatal deaths due to preterm birth complications. International Journal of Epidemiology, 39, i144-i154. doi:10.1093/ije/dyq031

Leader, L. R., Baillie, P., Martin, B., \& Vermeulen, E. (1982). The assessment and significance of habituation to a repeated stimulus by the human fetus. Early Human Development, 7(3), 211-219. doi:10. 1016/0378-3782(82)90084-6

Lecanuet, J.-P., \& Schaal, B. (1996). Fetal sensory competencies. European Journal of Obstetrics \& Gynecology and Reproductive Biology, 68, 1-23. doi:10.1016/0301-2115(96)02509-2

Lecanuet, J.-P., \& Schaal, B. (2002). Sensory performances in the human foetus: A brief summary of research. Intellectica, 1(34), 29-56.

Lehmann, J., \& Feldon, J. (2000). Long-term biobehavioral effects of maternal separation in the rat: Consistent or confusing? Reviews in the Neurosciences, 11(4), 383-408. doi:10.1515/REVNEURO. 2000.11.4.383

Lewkowicz, D. J., \& Turkewitz, G. (1981). Intersensory interaction in newborns - Modification of visual preferences following exposure to sound. Child Development, 52(3), 827-832. doi:10.2307/ 1129083
Lickliter, R. (1990a). Premature visual experience facilitates visual responsiveness in bobwhite quail neonates. Infant Behavior and Development, 13(4), 487-496. doi:10.1016/0163-6383(90)90018-4

Lickliter, R. (1990b). Premature visual stimulation accelerates intersenory functioning in bobwhite quail neonates. Developmental Psychobiology, 23(1), 15-27. doi:10.1002/dev.420230103

Lickliter, R. (1994). Prenatal visual experience alters postnatal sensory dominance hierarchy in bobwhite quail chicks. Infant Behavior and Development, 17(2), 185-193. doi:10.1016/0163-6383(94)90054-X

Lickliter, R. (2000). Atypical perinatal sensory stimulation and early perceptual development: Insights from developmental psychobiology. Journal of Perinatology: Official Journal of the California Perinatal Association, 20(8, Pt. 2), S45-S54.

Lickliter, R. (2005). Prenatal sensory ecology and experience: Implications for perceptual and behavioral development in precocial birds. In P. Slater, C. Snowdon, T. Roper, H. J. Brockmann, \& M. Naguib (Eds.), Advances in the study of behavior (Vol. 35, pp. 235 274). San Diego, CA: Academic Press.

Lickliter, R., \& Bahrick, L. E. (2007). Thinking about development: The value of animal-based research for the study of human development. European Journal of Developmental Science, 1(2), 172-183.

Lickliter, R., \& Hellewell, T. B. (1992). Contextual determinants of auditory learning in bobwhite quail embryos and hatchlings. Developmental Psychobiology, 25(1), 17-31. doi:10.1002/dev. 420250103

Liley, A. W. (1972). The foetus as a personality. Australian and New Zealand Journal of Psychiatry, 6(2), 99-105. doi:10.3109/ 00048677209159688

Liu, W. F., Laudert, S., Perkins, B., MacMillan-York, E., Martin, S., \& Graven, S. (2007). The development of potentially better practices to support the neurodevelopment of infants in the NICU. Journal of Perinatalogy, 27(S2), S48-S74.

Livera, M. D., Priya, B., Ramesh, A., Rao, P. N. S., Srilakshmi, V., Nagapoornima, M., ... Swarnarekha. (2008). Spectral analysis of noise in the neonatal intensive care unit. The Indian Journal of Pediatrics, 75(3), 217-222. doi:10.1007/ s12098-008-0048-Z

Long, J. G., Lucey, J. F., \& Philip, A. G. S. (1980). Noise and hypoxemia in the intensive care nursery. Pediatrics, 65(1), 143-145.

Long, J. G., Philip, A. G. S., \& Lucey, J. F. (1980). Excessive handling as a cause of hypoxemia. Pediatrics, 65(2), 203-207.

Mann, N. P., Haddow, R., Stokes, L., Goodley, S., \& Rutter, N. (1986). Effect of night and day on preterm infants in a newborn nursery: Randomised trial. British Medical Journal (Clinical Research Ed.), 293(6557), 1265-1267. doi:10.1136/bmj.293.6557.1265

Marcus, L., Lejeune, F., Berne-Audéoud, F., Gentaz, E., \& Debillon, T. (2012). Tactile sensory capacity of the preterm infant: Manual perception of shape from 28 gestational weeks. Pediatrics, $130(1)$, e88e94. doi:10.1542/peds.2011-3357

Marlier, L., Schaal, B., \& Soussignan, R. (1998a). Bottle-fed neonates prefer an odor experienced in utero to an odor experienced postnatally in the feeding context. Developmental Psychobiology, 33(2), 133-145. doi:10.1002/(sici)1098-2302(199809)33:2<133::aid$\operatorname{dev} 4>3.0 . c 0 ; 2-k$

Marlier, L., Schaal, B., \& Soussignan, R. (1998b). Neonatal responsiveness to the odor of amniotic and lacteal fluids: A test of perinatal chemosensory continuity. Child Development, 69(3), 611-623. doi: 10.1111/j.1467-8624.1998.tb06232.x

Mastropieri, D., \& Turkewitz, G. (1999). Prenatal experience and neonatal responsiveness to vocal expressions of emotion. Developmental Psychobiology, 35(3), 204-214. doi:10.1002/(SICI)10982302(199911)35:3<204::AID-DEV5>3.0.CO;2-V

Meltzoff, A. N., \& Keith, M. (1977). Imitation of facial and manual gestures by human neonates. Science, 198(4312), 75-78. doi:10. 1126/science.198.4312.75 
Mennella, J. A., Johnson, A., \& Beauchamp, G. K. (1995). Garlic ingestion by pregnant women alters the odor of amniotic fluid. Chemical Senses, 20(2), 207-209. doi:10.1093/chemse/20.2.207

Mikiel-Kostyra, K., Mazur, J., \& Boltruszko, I. (2002). Effect of early skin-to-skin contact after delivery on duration of breastfeeding: A prospective cohort study. Acta Paediatrica, 91(12), 1301-1306. doi: 10.1111/j.1651-2227.2002.tb02824.x

Miranda, S. B. (1970). Visual abilities and pattern preferences of premature infants and full-term neonates. Journal of Experimental Child Psychology, 10(2), 189-205. doi:10.1016/0022-0965(70)90071-8

Miranda-Morales, R. S., Nizhnikov, M. E., \& Spear, N. E. (2014). Prenatal exposure to ethanol during late gestation facilitates operant self-administration of the drug in 5-day-old rats. Alcohol, 48(1), 1923. doi:10.1016/j.alcohol.2013.11.001

Miura, M., \& Matsushima, T. (2012). Preference for biological motion in domestic chicks: Sex-dependent effect of early visual experience. Animal Cognition, 15(5), 871-879. doi:10.1007/s10071-012-0514-x

Molina, M., \& Jouen, F. (2003). Haptic intramodal comparison of texture in human neonates. Developmental Psychobiology, 42(4), 378-385. doi:10.1002/dev.10111

Mooncey, S., Giannakoulopoulos, X., Glover, V., Acolet, D., \& Modi, N. (1997). The effect of mother-infant skin-to-skin contact on plasma cortisol and $\beta$-endorphin concentrations in preterm newborns. Infant Behavior and Development, 20(4), 553-557. doi:10.1016/ S0163-6383(97)90045-X

Mooney, M. P., Siegel, M. I., \& Gest, T. R. (1985). Prenatal stress and increased fluctuating asymmetry in the parietal bones of neonatal rats. American Journal of Physical Anthropology, 68(1), 131-134. doi:10.1002/ajpa.1330680112

Mörelius, E., Hellström-Westas, L., Carlén, C., Norman, E., \& Nelson, N. (2006). Is a nappy change stressful to neonates? Early Human Development, 82(10), 669-676. doi:10.1016/j.earlhumdev.2005. 12.013

Morison, S. J., Holsti, L., Grunau, R. E., Whitfield, M. F., Oberlander, T. F., Chan, H. W. P., \& Williams, L. (2003). Are there developmentally distinct motor indicators of pain in preterm infants? Early Human Development, 72, 131-146. doi:10.1016/S0378-3782(03) 00044-6

Morlet, T., Lapillonne, A., Ferber, C., Duclaux, R., Sann, L., Putet, G., .. Collet, L. (1995). Spontaneous otoacoustic emissions in preterm neonates: Prevalence and gender effects. Hearing Research, 90(1/2), 44-54. doi:10.1016/0378-5955(95)00144-4

Nagy, E., Orvos, H., Bárdos, G., \& Molnár, P. (2000). Gender-related heart rate differences in human neonates. Pediatric Research, 47(6), 778-780. doi:10.1203/00006450-200006000-00016

Nakayasu, T., \& Watanabe, E. (2014). Biological motion stimuli are attractive to medaka fish. Animal Cognition, 17(3), 559-575. doi:10. 1007/s10071-013-0687-y

Owens, M. E., \& Todt, E. H. (1984). Pain in infancy: Neonatal reaction to a heel lance. Pain, 20(1), 77-86. doi:10.1016/0304-3959(84)90813-3

Parmelee, A. H., Wenner, W. H., Akiyama, Y., Schultz, M., \& Stern, E. (1967). Sleep states in premature infants. Developmental Medicine \& Child Neurology, 9(1), 70-77. doi:10.1111/j.1469-8749.1967. tb02212.x

Peirano, P., Curzi-Dascalova, L., \& Korn, G. (1986). Influence of sleep state and age on body motility in normal premature and full-term neonates. Neuropediatrics, 17(4), 186-190. doi:10.1055/s-20081052526

Peleg, D., \& Goldman, J. A. (1980). Fetal heart rate acceleration in response to light stimulation as a clinical measure of fetal well-being: A preliminary report. Journal of Perinatal Medicine, 8, 38-41. doi: 10.1515/jpme.1980.8.1.38

Petrikovsky, B. M., Schifrin, B., \& Diana, L. (1993). The effect of fetal acoustic stimulation on fetal swallowing and amniotic fluid index. Obstetrics \& Gynecology, 81(4), 548-550.
Philbin, M. K. (2000). The influence of auditory experience on the behavior of preterm newborns. Journal of Perinatology, 20(8, Pt. 2), S77-S87.

Philbin, M. K., Lickliter, R., \& Graven, S. N. (2000). Sensory experience and the developing organism: A history of ideas and view to the future. Journal of Perinatology: Official Journal of the California Perinatal Association, 20(8, Pt. 2), S2-S5.

Piatkina, G. (1982). Development of human olfactory receptors. Tsitologiia, 24(1), 11.

Pihet, S., Mellier, D., Bullinger, A., \& Schaal, B. (1997). Réponses comportementales aux odeurs chez le nouveau-né prématuré: Étude préliminaire. [Behavioral responses to odors in preterm infants: Preliminary study]. Enfance, 50(1), 33-46. doi: 10.3406/ enfan.1997.3044

Piontelli, A., Bocconi, L., Kustermann, A., Tassis, B., Zoppini, C., \& Nicolini, U. (1997). Patterns of evoked behaviour in twin pregnancies during the first 22 weeks of gestation. Early Human Development, 50(1), 39-45. doi:10.1016/S0378-3782(97)00091-1

Prazad, P., Cortes, D. R., Puppala, B. L., Donovan, R., Kumar, S., \& Gulati, A. (2008). Airborne concentrations of volatile organic compounds in neonatal incubators. Journal of Perinatology, 28(8), 534540. doi:10.1038/jp.2008.75

Prechtl, H. F. R. (1974). The behavioural states of the newborn infant (a review). Brain Research, 76(2), 185-212. doi:10.1016/00068993(74)90454-5

Pritchard, J. A. (1965). Deglutition by normal and anencephalic fetuses. Obstetrics \& Gynecology, 25(3), 289-297.

Pryce, C. R., Rüedi-Bettschen, D., Dettling, A. C., Weston, A., Russig, H., Ferger, B., \& Feldon, J. (2005). Long-term effects of early-life environmental manipulations in rodents and primates: Potential animal models in depression research. Neuroscience and Biobehavioral Reviews, 29, 649-674. doi:10.1016/j.neubiorev. 2005.03.011

Pujol, R., \& Lavigne-Rebillard, M. (1985). Early stages of innervation and sensory cell differentiation in the human fetal organ of Corti. Acta Oto-Laryngologica, 99, 43-50. doi:10.3109/ 00016488509122911

Pujol, R., \& Lavigne-Rebillard, M. (1992). Development of neurosensory structures in the human cochlea. Acta Oto-Laryngologica, 112, 259264. doi:10.1080/00016489.1992.11665415

Pujol, R., Lavigne-Rebillard, M., \& Uziel, A. (1991). Development of the human cochlea. Acta Oto-Laryngologica, 111, 7-13. doi:10.3109/ 00016489109128023

Pujol, R., Puel, J.-L., Gervais D'aldin, C., \& Eybalin, M. (1993). Pathophysiology of the glutamatergic synapses in the cochlea. Acta Oto-Laryngologica, 113(3), 330-334. doi:10.3109/ 00016489309135819

Puolakka, J., Kauppila, A., Leppäluoto, J., \& Vuolteenaho, O. (1982). Elevated $\beta$-endorphin immunoreactivity in umbilical cord blood after complicated delivery. Acta Obstetricia et Gynecologica Scandinavica, 61(6), 513-514. doi:10.3109/00016348209156604

Querleu, D., Renard, X., Boutteville, C., \& Crepin, G. (1989). Hearing by the human fetus? Seminars in Perinatology, 13, 409-420.

Querleu, D., Renard, X., Versyp, F., Paris-Delrue, L., \& Crèpin, G. (1988). Fetal hearing. European Journal of Obstetrics \& Gynecology and Reproductive Biology, 28(3), 191-212. doi:10. 1016/0028-2243(88)90030-5

Radell, P. L., \& Gottlieb, G. (1992). Developmental intersensory interference: Augmented prenatal sensory experience interferes with auditory learning in duck embryos. Developmental Psychology, 28(5), 795-803.

Ratynski, N., Cioni, G., Franck, L., Blanchard, Y., \& Sizun, J. (2002). The neonatal behavioral observation: A pertinent source of medical informations. Archives de Pédiatrie, 9(12), 1274-1279. doi:10.1016/ S0929-693X(02)00085-4 
Ricci, D., Cesarini, L., Groppo, M., De Carli, A., Gallini, F., Serrao, F., .. Mosca, F. (2008). Early assessment of visual function in full term newborns. Early Human Development, 84(2), 107-113. doi:10. 1016/j.earlhumdev.2007.03.010

Ricci, D., Romeo, D. M., Serrao, F., Cesarini, L., Gallini, F., Cota, F., ... Mercuri, E. (2008). Application of a neonatal assessment of visual function in a population of low risk full-term newborn. Early Human Development, 84, 277-280. doi:10.1016/j.earlhumdev. 2007.10.002

Ricci, D., Romeo, D. M., Serrao, F., Gallini, F., Leone, D., Longo, M., ... Mercuri, E. (2010). Early assessment of visual function in preterm infants: How early is early? Early Human Development, 86(1), 29 33. doi:10.1016/j.earlhumdev.2009.11.004

Richards, D. S., Frentzen, B., Gerhardt, K. J., Mccann, M. E., \& Abrams, R. M. (1992). Sound levels in the human uterus. Obstetrics \& Gynecology, 80(2), 186-190.

Rivkees, S. A., Mayes, L., Jacobs, H., \& Gross, I. (2004). Rest-activity patterns of premature infants are regulated by cycled lighting. Pediatrics, 113(4), 833-839.

Rogers, L. J. (2008). Development and function of lateralization in the avian brain. Brain Research Bulletin, 76(3), 235-244. doi:10.1016/j. brainresbull.2008.02.001

Rogers, L. J. (2014). Asymmetry of brain and behavior in animals: Its development, function, and human relevance. Genesis, 52(6), 555 571. doi:10.1002/dvg.22741

Romeo, D. M., Ricci, D., Serrao, F., Gallini, F., Olivieri, G., Cota, F., ... Mercuri, E. (2012). Visual function assessment in late-preterm newborns. Early Human Development, 88(5), 301-305. doi:10.1016/j. earlhumdev.2011.08.024

Ronca, A., Fritzsch, B., Bruce, L. L., \& Alberts, J. R. (2008). Orbital spaceflight during pregnancy shapes function of mammalian vestibular system. Behavioral Neuroscience, 122(1), 224-232. doi:10. 1037/0735-7044.122.1.224

Rönnqvist, L., \& Hopkins, B. (1998). Head position preference in the human newborn: A new look. Child Development, 69(1), 13-23. doi:10.1111/j.1467-8624.1998.tb06129.x

Rosa Salva, O., Farroni, T., Regolin, L., Vallortigara, G., \& Johnson, M. H. (2011). The evolution of social orienting: Evidence from chicks (Gallus gallus) and human newborns. PLoS ONE, 6(4), e18802. doi: 10.1371/journal.pone.0018802

Rosa Salva, O., Mayer, U., \& Vallortigara, G. (2015). Roots of a social brain: Developmental models of emerging animacy-detection mechanisms. Neuroscience \& Biobehavioral Reviews, 50, 150-168. doi: 10.1016/j.neubiorev.2014.12.015

Rosa Salva, O., Regolin, L., \& Vallortigara, G. (2010). Faces are special for newly hatched chicks: Evidence for inborn domain-specific mechanisms underlying spontaneous preferences for face-like stimuli. Developmental Science, 13(4), 565-577. doi:10.1111/j.14677687.2009.00914.x

Rosa Salva, O., Regolin, L., \& Vallortigara, G. (2012). Inversion of contrast polarity abolishes spontaneous preferences for face-like stimuli in newborn chicks. Behavioural Brain Research, 228(1), 133-143. doi:10.1016/j.bbr.2011.11.025

Rosenstein, D., \& Oster, H. (1988). Differential facial responses to four basic tastes in newborns. Child Development, 59(6), 1555-1568. doi: $10.2307 / 1130670$

Rotteveel, J. J., de Graaf, R., Colon, E. J., Stegeman, D. F., \& Visco, Y. M. (1987). The maturation of the central auditory conduction in preterm infants until three months post term: II. The auditory brainstem responses (ABRs). Hearing Research, 26(1), 21-35. doi:10.1016/ 0378-5955(87)90033-5

Rugani, R., Rosa Salva, O., Regolin, L., \& Vallortigara, G. (2015). Brain asymmetry modulates perception of biological motion in newborn chicks (Gallus gallus). Behavioural Brain Research, 290, 1-7. doi: 10.1016/j.bbr.2015.04.032
Sann, C., \& Streri, A. (2007). Perception of object shape and texture in human newborns: Evidence from cross-modal transfer tasks. Developmental Science, 10(3), 399-410. doi:10.1111/j.1467-7687. 2007.00593.x

Sarnat, H. B. (1978). Olfactory reflexes in the newborn infant. The Journal of Pediatrics, 92(4), 624-626. doi:10.1016/S00223476(78)80307-2

Schaal, B., Hummel, T., \& Soussignan, R. (2004). Olfaction in the fetal and premature infant: Functional status and clinical implications. Clinics in Perinatology, 31(2), 261. doi:10.1016/j.clp.2004.04.003

Schaal, B., Marlier, L., \& Soussignan, R. (1995). Responsiveness to the odour of amniotic fluid in the human neonate. Neonatology, 67(6), 397-406. doi:10.1159/000244192

Schaal, B., Marlier, L., \& Soussignan, R. (1998). Olfactory function in the human fetus: Evidence from selective neonatal responsiveness to the odor of amniotic fluid. Behavioral Neuroscience, 112(6), 14381449. doi:10.1037/0735-7044.112.6.1438

Schaal, B., Marlier, L., \& Soussignan, R. (2000). Human foetuses learn odours from their pregnant mother's diet. Chemical Senses, 25(6), 729-737. doi:10.1093/chemse/25.6.729

Scher, M. S., Ludington-Hoe, S., Kaffashi, F., Johnson, M. W., HolditchDavis, D., \& Loparo, K. A. (2009). Neurophysiologic assessment of brain maturation after an 8-week trial of skin-to-skin contact on preterm infants. Clinical Neurophysiology, 120(10), 1812-1818. doi:10.1016/j.clinph.2009.08.004

Schleidt, M., \& Genzel, C. (1990). The significance of mother's perfume for infants in the first weeks of their life. Ethology and Sociobiology, 11(3), 145-154. doi:10.1016/0162-3095(90)90007-S

Simion, F., Regolin, L., \& Bulf, H. (2008). A predisposition for biological motion in the newborn baby. Proceedings of the National Academy of Sciences, 105(2), 809-813. doi:10.1073/pnas.0707021105

Sininger, Y. S., Abdala, C., \& Cone-Wesson, B. (1997). Auditory threshold sensitivity of the human neonate as measured by the auditory brainstem response. Hearing Research, 104(1/2), 27-38. doi:10. 1016/S0378-5955(96)00178-5

Sizun, J., Ansquer, H., Browne, J. V., Tordjman, S., \& Morin, J.-F. (2002). Developmental care decreases physiologic and behavioral pain expression in preterm neonates. The Journal of Pain, 3(6), 446-450. doi:10.1054/jpai.2002.128066

Slater, R., Cantarella, A., Gallella, S., Worley, A., Boyd, S., Meek, J., \& Fitzgerald, M. (2006). Cortical pain responses in human infants. The Journal of Neuroscience, 26(14), 3662-3666. doi:10.1523/ JNEUROSCI.0348-06.2006

Slater, R., Cantarella, A., Yoxen, J., Patten, D., Potts, H., Meek, J., \& Fitzgerald, M. (2009). Latency to facial expression change following noxious stimulation in infants is dependent on postmenstrual age. Pain, 146(1/2), 177-182. doi:10.1016/j.pain.2009.07.022

Slater, R., Cornelissen, L., Fabrizi, L., Patten, D., Yoxen, J., Worley, A., ... Fitzgerald, M. (2010). Oral sucrose as an analgesic drug for procedural pain in newborn infants: A randomised controlled trial. The Lancet, 376(9748), 1225-1232. doi:10.1016/S0140-6736(10) 61303-7

Slater, A., Morison, V., Town, C., \& Rose, D. (1985). Movement perception and identity constancy in the new-born baby. British Journal of Developmental Psychology, 3(3), 211-220. doi:10.1111/j.2044835X.1985.tb00974.x

Slater, A., Von der Schulenburg, C., Brown, E., Badenoch, M., Butterworth, G., Parsons, S., \& Samuels, C. (1998). Newborn infants prefer attractive faces. Infant Behavior and Development, 21(2), 345-354. doi:10.1016/S0163-6383(98)90011-X

Sleigh, M. J., \& Lickliter, R. (1995). Augmented prenatal visual stimulation alters postnatal auditory and visual responsiveness in bobwhite quail chicks. Developmental Psychobiology, 28(7), 353-366. doi: 10.1002/dev.420280702

Smyth, C. N. (1965). Exploratory methods for testing the integrity of the foetus and neonate. International Journal of Obstetrics \& 
Gynaecology, 72(6), 920-925. doi:10.1111/j.1471-0528.1965. tb01513.x

Soussignan, R., Schaal, B., Marlier, L., \& Jiang, T. (1997). Facial and autonomic responses to biological and artificial olfactory stimuli in human neonates: Re-examining early hedonic discrimination of odors. Physiology \& Behavior, 62(4), 745-758. doi:10.1016/ S0031-9384(97)00187-X

Starr, A., Amlie, R. N., Martin, W. H., \& Sanders, S. (1977). Development of auditory function in newborn infants revealed by auditory brainstem potentials. Pediatrics, 60(6), 831-839.

Steiner, J. E. (1979). Human facial expressions in response to taste and smell stimulation. Advances in Child Development and Behavior, 13, 257-295.

Steiner, J. E., Glaser, D., Hawilo, M. E., \& Berridge, K. C. (2001). Comparative expression of hedonic impact: Affective reactions to taste by human infants and other primates. Neuroscience and Biobehavioral Reviews, 25(1), 53-74. doi:10.1037/0735-7044.112. 6.1438

Stevens, B. J., Johnston, C. C., \& Horton, L. (1994). Factors that influence the behavioral pain responses of premature infants. Pain, 59(1), 101-109. doi:10.1016/0304-3959(94)90053-1

Streri, A., \& Gentaz, E. (2004). Cross-modal recognition of shape from hand to eyes and handedness in human newborns. Neuropsychologia, 42(10), 1365-1369. doi:10.1016/j. neuropsychologia.2004.02.012

Streri, A., Lhote, M., \& Dutilleul, S. (2000). Haptic perception in newborns. Developmental Science, 3(3), 319-327. doi:10.1111/14677687.00126

Sugita, Y. (2008). Face perception in monkeys reared with no exposure to faces. Proceedings of the National Academy of Sciences, 105(1), 394-398. doi:10.1073/pnas.0706079105

Takahashi, Y., Tamakoshi, K., Matsushima, M., \& Kawabe, T. (2011). Comparison of salivary cortisol, heart rate, and oxygen saturation between early skin-to-skin contact with different initiation and duration times in healthy, full-term infants. Early Human Development, 87(3), 151-157. doi:10.1016/j.earlhumdev.2010.11. 012

Tallet, C., Rakotomahandry, M., Guérin, C., Lemasson, A., \& Hausberger, M. (2016). Postnatal auditory preferences in piglets differ according to maternal emotional experience with the same sounds during gestation. Scientific Reports, 6. doi:10.1038/ srep37238

Tatzer, E., Schubert, M. T., Timischl, W., \& Simbruner, G. (1985). Discrimination of taste and preference for sweet in premature babies. Early Human Development, 12(1), 23-30. doi:10.1016/03783782(85)90133-1

Taylor, M. J., Menzies, R., MacMillan, L. J., \& Whyte, H. E. (1987). VEP's in normal full-term and premature neonates: Longitudinal versus cross-sectional data. Electroencephalography and Clinical Neurophysiology/Evoked Potentials Section, 68(1), 20-27. doi:10. 1016/0168-5597(87)90066-9

Thordstein, M., Löfgren, N., Flisberg, A., Lindecrantz, K., \& Kjellmer, I. (2006). Sex differences in electrocortical activity in human neonates. Neuroreport, 17(11), 1165-1168. doi:10.1097/01.wnr.0000227978. 98389.43

Tristão, R. M., Garcia, N. V. M., de Jesus, J. A. L., \& Tomaz, C. (2013). COMFORT behaviour scale and skin conductance activity: What are they really measuring? Acta Paediatrica, 102(9), e402-e406. doi:10.1111/apa.12325

Turkewitz, G., Birch, H. G., Moreau, T., Levy, L., \& Cornwell, A. C. (1966). Effect of intensity of auditory stimulation on directional eye movements in the human neonate. Animal Behaviour, 14(1), 93101. doi:10.1016/S0003-3472(66)80016-7

Turkewitz, G., \& Kenny, P. A. (1982). Limitations on input as a basis for neural organization and perceptual development: A preliminary theoretical statement. Developmental Psychobiology, 15(4), 357-368. doi:10.1002/dev.420150408

Vallortigara, G. (2012). Aristotle and the chicken: Animacy and the origins of beliefs. In A. Fasolo (Ed.), The theory of evolution and its impact (pp. 189-199). Milano, Italy: Springer Milan.

Vallortigara, G., Regolin, L., \& Marconato, F. (2005). Visually inexperienced chicks exhibit spontaneous preference for biological motion patterns. PLoS Biology, 3(7), e208. doi:10.1371/journal.pbio. 0030208

Ververs, I. A. P., de Vries, J. I. P., van Geijn, H. P., \& Hopkins, B. (1994). Prenatal head position from 12-38 weeks: I. Developmental aspects. Early Human Development, 39(2), 83-91. doi:10.1016/03783782(94)90157-0

Visser, G. H. A., Mulder, H. H., Wit, H. P., Mulder, E. J. H., \& Prechtl, H. F. R. (1989). Vibro-acoustic stimulation of the human fetus: Effect on behavioural state organization. Early Human Development, 19(4), 285-296. doi:10.1016/0378-3782(89)90063-7

Vistamehr, S., \& Tian, N. (2004). Light deprivation suppresses the light response of inner retina in both young and adult mouse. Visual Neuroscience, 21(01), 23-37. doi:10.1017/S0952523804041033

Walker, D., Grimwade, J., \& Wood, C. (1973). The effects of pressure on fetal heart rate. Obstetrics \& Gynecology, 41(3), 351-354.

Weinacht, S., Kind, C., Mönting, J. S., \& Gottlob, I. (1999). Visual development in preterm and full-term infants: A prospective masked study. Investigative Ophthalmology \& Visual Science, 40(2), 346353.

Weinert, D., Sitka, U., Minors, D., Menna-Barreto, L., \& Waterhouse, J. (1997). Twenty-four-hour and ultradian rhythmicities in healthy fullterm neonates: Exogenous and endogenous influences. Biological Rhythm Research, 28(4), 441-452. doi:10.1076/brhm.28.4.441. 13119

White, R. D. (2011a). Designing environments for developmental care. Clinics in Perinatology, 38(4), 745-749. doi:10.1016/j.clp.2011.08. 012

White, R. D. (2011b). The newborn intensive care unit environment of care: How we got here, where we're headed, and why. Seminars in Perinatology, 35(1), 2-7. doi:10.1053/j.semperi.2010.10.002

White, C. P., \& Cooke, R. W. I. (1989). Maturation of the cortical evoked response to posterior-nerve stimulation in the preterm neonate. Developmental Medicine \& Child Neurology, 31(5), 657-664. doi: 10.1111/j.1469-8749.1989.tb04052.x

Witt, M., \& Reutter, K. (1997). Scanning electron microscopical studies of developing gustatory papillae in humans. Chemical Senses, 22(6), 601-612. doi:10.1093/chemse/22.6.601

Witt, M., \& Reutter, K. (1998). Innervation of developing human taste buds. An immunohistochemical study. Histochemistry and Cell Biology, 109(3), 281-291. doi:10.1007/s004180050228

Woodward, A., Phillips, A., \& Spelke, E. S. (1993). Infants' expectations about the motions of inanimate vs. animate objects. Proceedings of the Cognitive Science Society. Hillsdale, NJ: Erlbaum.

Zimmer, E. Z., Divon, M. Y., Vilensky, A., Sarna, Z., Peretz, B. A., \& Paldi, E. (1982). Maternal exposure to music and fetal activity. European Journal of Obstetrics \& Gynecology and Reproductive Biology, 13(4), 209-213. doi:10.1016/0028-2243(82)90101-0

Zimmer, E. Z., Goldstein, I., \& Alglay, S. (1988). Simultaneous recording of fetal breathing movements and body movements in twin pregnancy. Journal of Perinatal Medicine, 16(2), 109-111. doi:10.1515/ jpme.1988.16.2.109 